\title{
The role of microRNAs in Helicobacter pylori pathogenesis and gastric carcinogenesis
}

\author{
Jennifer M. Noto ${ }^{1 *}$ and Richard M. Peek ${ }^{1,2}$ \\ 1 Division of Gastroenterology, Department of Medicine, Vanderbilt University Medical Center, Nashville, TN, USA \\ ${ }^{2}$ Department of Cancer Biology, Vanderbilt University Medical Center, Nashville, TN, USA
}

\section{Edited by:}

D. Scott Merrell, Uniformed Services University, USA

\section{Reviewed by:}

Anne Müller, University of Zurich, Switzerland

Fabien Darfeuille, INSERM, France Aime Franco, University of Arkansas for Medical Sciences, USA

\section{*Correspondence:}

Jennifer M. Noto, Division of Gastroenterology, Department of Medicine, Vanderbilt University Medical Center, 2215 Garland

Avenue, 1030C MRB IV, Nashville, TN 37232-0252, USA.

e-mail: jennifer.noto@vanderbilt.edu
Gastric carcinogenesis is a multistep process orchestrated by aberrancies in the genetic and epigenetic regulation of oncogenes and tumor suppressor genes. Chronic infection with Helicobacter pylori is the strongest known risk factor for the development of gastric cancer. H. pylori expresses a spectrum of virulence factors that dysregulate host intracelIular signaling pathways that lower the threshold for neoplastic transformation. In addition to bacterial determinants, numerous host and environmental factors increase the risk of gastric carcinogenesis. Recent discoveries have shed new light on the involvement of microRNAs (miRNAs) in gastric carcinogenesis. miRNAs represent an abundant class of small, non-coding RNAs involved in global post-transcriptional regulation and, consequently, play an integral role at multiple steps in carcinogenesis, including cell cycle progression, proliferation, apoptosis, invasion, and metastasis. Expression levels of miRNAs are frequently altered in malignancies, where they function as either oncogenic miRNAs or tumor suppressor miRNAs. This review focuses on miRNAs dysregulated by $\mathrm{H}$. pylori and potential etiologic roles they play in $H$. pylori-mediated gastric carcinogenesis.

\section{INTRODUCTION}

Microbial infections are among the most significant causes of cancer worldwide with nearly one in five malignancies resulting from infectious agents (Parkin, 2006). Gastrointestinal cancers represent a major global health concern and account for nearly $20 \%$ of all cancer-related deaths (Ferlay et al., 2007). Despite the decreasing incidence of gastric cancer in developed countries, it remains the second leading cause of cancer-related death throughout the world, with $\sim 700,000$ deaths attributed to this malignancy annually (Parkin et al., 2005). The major contributing factor to the development of gastric cancer is colonization and chronic infection by the bacterial pathogen, Helicobacter pylori. H. pylori selectively colonizes the gastric epithelium of over $50 \%$ of the world's population and typically persists for the lifetime of the host. Among colonized individuals, however, only a fraction develop gastric adenocarcinoma, emphasizing the importance of understanding the pathogenic mechanisms by which $\mathrm{H}$. pylori promotes chronic inflammation and the progression to gastric cancer.

\section{VIRULENCE FACTORS THAT MEDIATE HELICOBACTER PYLORI PATHOGENESIS}

Chronic gastric inflammation induced by the bacterial pathogen, $H$. pylori, is the strongest known risk factor for the development of atrophic gastritis, metaplasia, dysplasia, and ultimately gastric adenocarcinoma (Figure 1). H. pylori is a Gram-negative, helicalshaped bacterium specifically adapted to persist within the human gastric niche. H. pylori possesses numerous elements to successfully colonize the gastric mucosa, establish chronic infection, and induce gastric pathology. In vivo, approximately $20 \%$ of $\mathrm{H}$. pylori adhere to the gastric epithelium (Hessey et al., 1990). The large repertoire of adhesins expressed by $H$. pylori likely contribute to its specific adaptation to the gastric niche, allowing flexibility to target specific host cells and to exert a dynamic range of effector functions on host cells. H. pylori expresses a number of adhesins that have been linked to virulence. SabA (sialic acidbinding adhesin), which binds host sialyl-Lewis ${ }^{\mathrm{x}}$, contributes to $H$. pylori persistence and mediates chronic gastric inflammation and injury (Mahdavi et al., 2002). The presence of blood group antigen-binding adhesin (BabA), which binds the host Lewis ${ }^{\mathrm{b}}$ blood group antigen, increases the risk of gastric cancer in a synergistic fashion with other virulence factors, such as CagA (Ilver et al., 1998; Gerhard et al., 1999).

Following adherence and colonization of the gastric mucosa, H. pylori induces chronic gastritis and gastric injury, which are characterized by both neutrophilic and lymphocytic inflammation (Marshall et al., 1985; Goodwin et al., 1986). H. pylori expresses a number of factors capable of modulating the host immune system and eliciting proinflammatory immune responses. Some of these virulence factors include vacuolating cytotoxin (VacA) and the cag (cytotoxin associated gene) pathogenicity island. VacA is coded by the gene vacA, which is present in all strains of $H$. pylori, and which exhibits vacuolating activity (Leunk et al., 1988; Cover and Blaser, 1992; Cover et al., 1994; Phadnis et al., 1994; Schmitt and Haas, 1994; Telford et al., 1994). Additionally, VacA can induce apoptosis of host cells (Kuck et al., 2001; Xia and Talley, 2001) and suppress proliferation of $\mathrm{T}$ and $\mathrm{B}$ lymphocytes (Boncristiano et al., 2003; Gebert et al., 2003; Sundrud et al., 2004), which may contribute to the persistence of $H$. pylori through dysregulation of the host immune response. The cag pathogenicity island is present in 


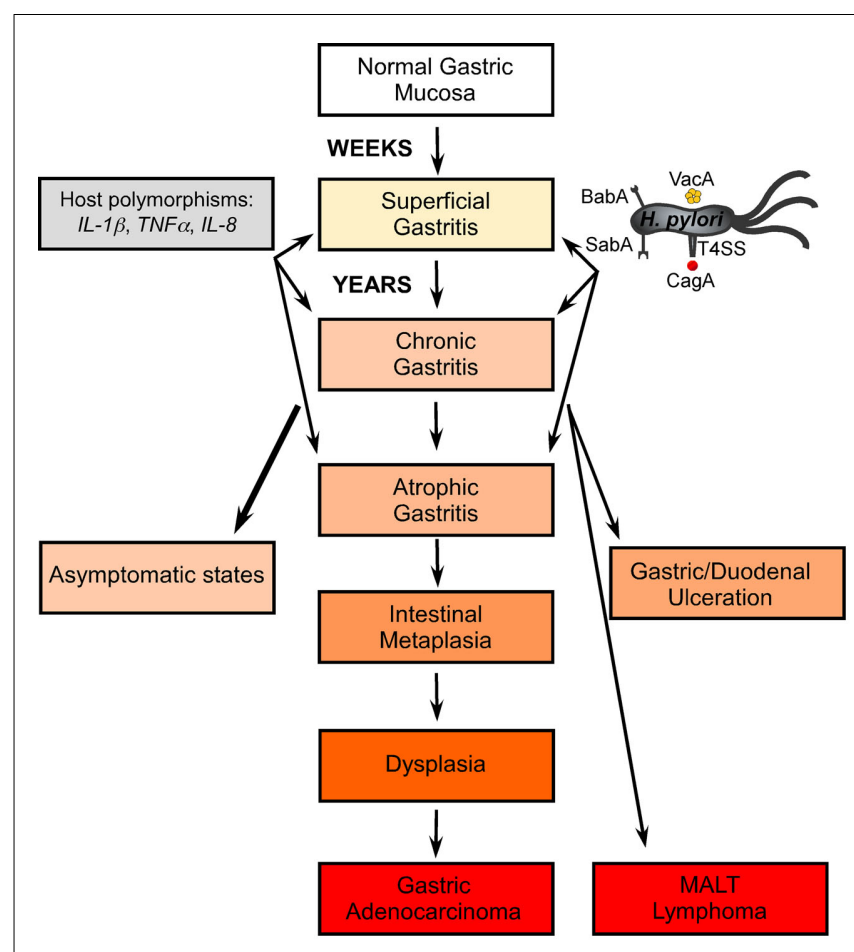

FIGURE 1 | Progression to gastric adenocarcinoma. H. pylori colonizes the human gastric mucosa and causes superficial gastritis and chronic inflammation over weeks to months. $H$. pylori expressing key virulence factors, such as the cag type 4 secretion system (T4SS), and host genetic polymorphisms in $I L-1 \beta, T N F \alpha$, and $I L-8$ promoters that promote high expression of proinflammatory cytokines, augment the risk for developing atrophic gastritis, intestinal metaplasia, dysplasia, and ultimately, gastric adenocarcinoma

$\sim 60 \%$ of all $H$. pylori strains and its presence is strongly associated with an increased risk of severe gastritis, ulcer disease, and gastric cancer (Censini et al., 1996; Tomb et al., 1997; Akopyants et al., 1998; Alm et al., 1999). The cag island encodes a type 4 secretion system (T4SS), which injects effector molecules, such as CagA, into host cells. CagA is a $120-$ to $140-\mathrm{kD}$ protein that contains a number of tyrosine phosphorylation motifs (Covacci et al., 1993; Tummuru et al., 1993). Following its injection into host cells, CagA exerts a wide range of phosphorylation-dependent and independent effects, such as cytoskeletal rearrangements, disruption of cell polarity, and mitogenic and proinflammatory responses (Polk and Peek, 2010). Cumulatively, these bacterial factors contribute to adherence, persistence, host immune modulation, and virulence of $H$. pylori within the gastric niche, ultimately resulting in $H$. pylori-mediated chronic inflammation and a series of pathological outcomes that facilitate the development of gastric cancer.

\section{HOST FACTORS THAT CONTRIBUTE TO GASTRIC CARCINOGENESIS}

In addition to microbial factors that potentiate gastric disease, there are a number of host factors that contribute to chronic gastritis and the progression to gastric adenocarcinoma. Cyclooxygenases (COX) are key enzymes that catalyze prostaglandin synthesis. Of the three isoforms identified, COX-2 is upregulated in gastric epithelial cells upon co-culture with $H$. pylori (Romano et al., 1998; Juttner et al., 2003; Meyer et al., 2003; Wu et al., 2005) and within the gastric mucosa of $H$. pylori-infected individuals (Sawaoka et al., 1998; Fu et al., 1999; McCarthy et al., 1999). In vivo studies show that COX-2 is further upregulated in H. pylori-mediated adenocarcinoma (Ristimaki et al., 1997; Sung et al., 2000). COX-2 expression levels are considered an independent factor for poor prognosis and correlate with reduced patient survival, suggesting that $H$. pylori-induced COX-2 overexpression is a risk factor for the development of gastric cancer.

Other host factors that increase the propensity for chronic inflammation and gastric adenocarcinoma are polymorphisms within human $I L-1 \beta$ (interleukin-1), TNF- $\alpha$ (tumor necrosis factor), and $I L-8$ promoters (El-Omar et al., 2000, 2003; Machado et al., 2001; Furuta et al., 2002), which lead to increased expression of the proinflammatory cytokines IL- $1 \beta$, TNF- $\alpha$, and IL- 8 (Figure 1). These polymorphisms in combination with $H$. pylori virulent genotypes increase the risk of gastric cancer up to 87-fold over baseline (Figueiredo et al., 2002), emphasizing the importance of microbial-host interactions in the development of gastric cancer. Collectively, data demonstrate that $H$. pylori virulence factors, host genetics, and environmental factors interact to induce and maintain the persistent inflammatory immune response that initiates the multistep process leading to gastric cancer.

\section{microRNAs}

Recent discoveries have shed new light on the involvement of host microRNAs (miRNAs) in gastric carcinogenesis. miRNAs are small, non-coding RNAs $\sim 20-25$ nucleotides in length, which function as critical post-transcriptional regulators of gene expression (Bartel, 2009). miRNAs were first characterized in 1993 (Lee et al., 1993), but their distinct role in transcriptional regulation was not recognized until the early 2000s. Most miRNAs are found in intergenic regions and contain their own promoter and regulatory units. Processed miRNAs function by binding to the $3^{\prime}$ untranslated region ( $3^{\prime} \mathrm{UTR}$ ) of messenger RNAs (mRNAs), typically resulting in mRNA degradation and gene silencing or translational repression (Bartel, 2009). It is estimated that the human genome encodes thousands of miRNAs, targeting 30-60\% of all protein-coding genes (Lewis et al., 2003). miRNAs are involved in many biological processes, including development, differentiation, angiogenesis, cell cycle progression, proliferation, apoptosis, and signal transduction pathways (Ambros, 2004). Dysregulation of miRNA expression with subsequent disruption of these biological processes can result in disease states. There is an increasing body of evidence regarding the regulatory roles of miRNAs in immune and inflammatory disorders (Wu et al., 2008; Sonkoly and Pivarcsi, 2009), and aberrant expression of miRNAs is observed in many cancers (Lu et al., 2005; Volinia et al., 2006). Thus, recent studies have begun to dissect the mechanisms by which miRNAs function as either oncogenic miRNAs (oncomiRs) or tumor suppressors to promote or prevent tumorigenesis.

\section{DYSREGULATION OF MIRNAS IN H. PYLORI-INDUCED GASTRIC CARCINOGENESIS}

The number of studies analyzing miRNA expression profiles in gastric cancer is rapidly increasing and a comprehensive list of 
miRNAs dysregulated in gastric cancer, confirmed mRNA targets, and the biological processes affected is shown in Tables A1 and A2 in the Appendix. The first study to address miRNA expression profiles in various cancers, including gastric cancer, was performed in 2005 (Lu et al., 2005). Subsequent studies have not only focused on miRNA expression profiles in gastric cancer, but also those that are altered in response to $H$. pylori.

Matsushima et al. (2011) conducted a study to characterize miRNA expression signatures in $H$. pylori-infected human gastric mucosa. Using high throughput profiling analysis, $31 \mathrm{miR}-$ NAs were identified as being differentially expressed between $H$. pylori-infected and $H$. pylori-uninfected gastric mucosa. The relationship between miRNA expression levels and $H$. pylori-induced acute inflammation, characterized by neutrophil infiltration, and chronic inflammation, characterized by mononuclear cell infiltration were also determined. Expression levels of many miRNAs correlated with either the degree of acute or chronic inflammation and in some cases both (Tables 1 and 2). The relationship between miRNA expression and extent of glandular atrophy, and intestinal metaplasia was also assessed, but no significant correlations were found (Matsushima et al., 2011). A comprehensive list of miRNAs dysregulated by $H$. pylori, confirmed mRNA targets, and biological processes affected is shown in Tables 1 and 2 . These data suggest that $H$. pylori infection affects global miRNA expression in human gastric mucosa, and this effect is, in part, linked to $H$. pylori-induced host inflammatory immune responses.

miRNAs that are dysregulated in response to $H$. pylori infection may not be the same miRNAs that are dysregulated in later stages of gastric disease. A comprehensive review of the literature, however, revealed that there is a select subset of miRNAs dysregulated both following $H$. pylori infection as well asin gastric cancer. These include downregulated miRNAs, let-7a, miR-31, miR-101, miR-141, $m i R-203, m i R-210, m i R-218, m i R-375$, and $m i R-449$ as well as upregulated miRNAs, $m i R-17, m i R-20 a, m i R-21, m i R-146 a$, $m i R-155$, and $m i R-223$. These miRNAs may be more biologically relevant to $H$. pylori-induced gastric inflammation and carcinogenesis and represent fruitful targets for studies focused on cancer that develops in the context of H. pylori infection.

The next sections will discuss miRNA dysregulation in $H$. pylori-induced disease and how specific miRNAs control various biological processes related to (1) host inflammatory immune response, (2) cell cycle progression, and (3) apoptosis and proliferation.

\section{HELICOBACTER PYLORI-INDUCED MIRNA DYSREGULATION TO CONTROL HOST INFLAMMATORY RESPONSES}

Host cells recognize invading pathogens and/or pathogenassociated molecular patterns (PAMPs) through membraneassociated or cytoplasmic pathogen recognition molecules known as Toll-like receptors (TLRs) and Nod-like receptors (NLRs), respectively. PAMPs activate adaptor proteins and transcription factors that mediate host innate immunity through activation of NF- $\kappa \mathrm{B}$ (nuclear factor kappa-light-chain-enhancer of activated B cells) signaling (Figure 2). Gastric epithelial cells are the initial host element encountered by $H$. pylori. The innate immune response induced in epithelial cells is characterized by NOD1-dependent activation of NF- $\mathrm{KB}$ in response to $H$. pylori peptidoglycan (PGN), which is injected into host cells via the cag T4SS (Viala et al., 2004). Activation of NF- $\kappa \mathrm{B}$ by $H$. pylori leads to induction of the proinflammatory cytokine IL-8 and likely contributes to carcinogenesis through activation of downstream targets that mediate inflammation, cell cycle progression, proliferation, and apoptosis. Myeloid cells constitute a second line of defense and secrete proinflammatory cytokines such as IL-6, IL-1, and TNF- $\alpha$ to establish T and B lymphocyte-mediated adaptive immunity.

The involvement of miRNAs in modulating both the innate and adaptive immune responses is well established (Chen et al., 2004) and H. pylori can dysregulate miRNA expression to evade host defenses and successfully persist in the gastric niche. $m i R$ $146 a$ and $m i R-155$ are specifically involved in $H$. pylori-induced negative regulation of the proinflammatory immune response (Figure 2). Changes in miR-146a expression occur in the development of gastric cancer and in the negative regulation of the innate inflammatory immune response. Single-nucleotide polymorphisms (SNPs) in $m i R-146 a$ are associated with an increased susceptibility to gastric cancer (Okubo et al., 2010) and $H$. pylori upregulates miR-146a in vitro and in vivo in a CagAindependent and an NF- $\kappa$ B-dependent manner (Liu et al., 2010; Li et al., 2011a). miR-146a targets the TLR-signaling adaptor molecules IRAK1 (interleukin-1 receptor-associated kinase) and TRAF6 (TNF receptor-associated factor), resulting in negative regulation of TLR and downstream proinflammatory signaling (Figure 2; Liu et al., 2010; Li et al., 2011a). As a result, miR-146a overexpression negatively regulates $H$. pylori-induced IL-8, TNF$\alpha, \mathrm{IL}-1 \beta, \mathrm{GRO}-\alpha$ [CXCL1, chemokine (C-X-C motif) ligand], and MIP-3 $\alpha$ (macrophage inflammatory protein) expression, all key components to the proinflammatory innate and adaptive immune responses (Liu et al., 2010; Li et al., 2011a).

The second miRNA involved in $H$. pylori-induced downregulation of the host inflammatory immune response, $m i R-155$, plays a critical role in regulating lymphocyte homeostasis and tolerance (Thai et al., 2007). miR-155 is increased in many malignancies of B cell or myeloid origin (Volinia et al., 2006). In transgenic murine models of $m i R-155$ overexpression, mice develop spontaneous B cell lymphomas (Costinean et al., 2006). miR-155 is induced during both bacterial and viral infections in myeloid cells through activation of TLR-signaling pathways. H. pylori upregulates miR-155 expression in vitro and in vivo, which occurs in an NF- $\kappa$ B-dependent manner, and ultimately results in decreased induction of the proinflammatory cytokines, IL-8, and GRO- $\alpha$ (Xiao et al., 2009b; Tang et al., 2010). miR-155 targets MyD88 (myeloid differentiation primary response gene), the universal adapter protein used by TLRs to activate NF- $\kappa \mathrm{B}$ (Figure 2; Xiao et al., 2009b; Tang et al., 2010). Decreased levels of MyD88 subsequently result in decreased NF- $\kappa \mathrm{B}$ activation and dampening of the host inflammatory response (Xiao et al., 2009b; Tang et al., 2010). Therefore, these data demonstrate that $H$. pylori dysregulates host miRNA expression to manipulate the host inflammatory immune response, which may promote bacterial survival and persistence within the gastric mucosa. Because these miRNAs have established roles in carcinogenesis as well as innate immunity, they could serve as an important link between $H$. pylori-induced inflammation and carcinogenesis. 
Table 1 | miRNAs downregulated in response to $\boldsymbol{H}$. pylori.

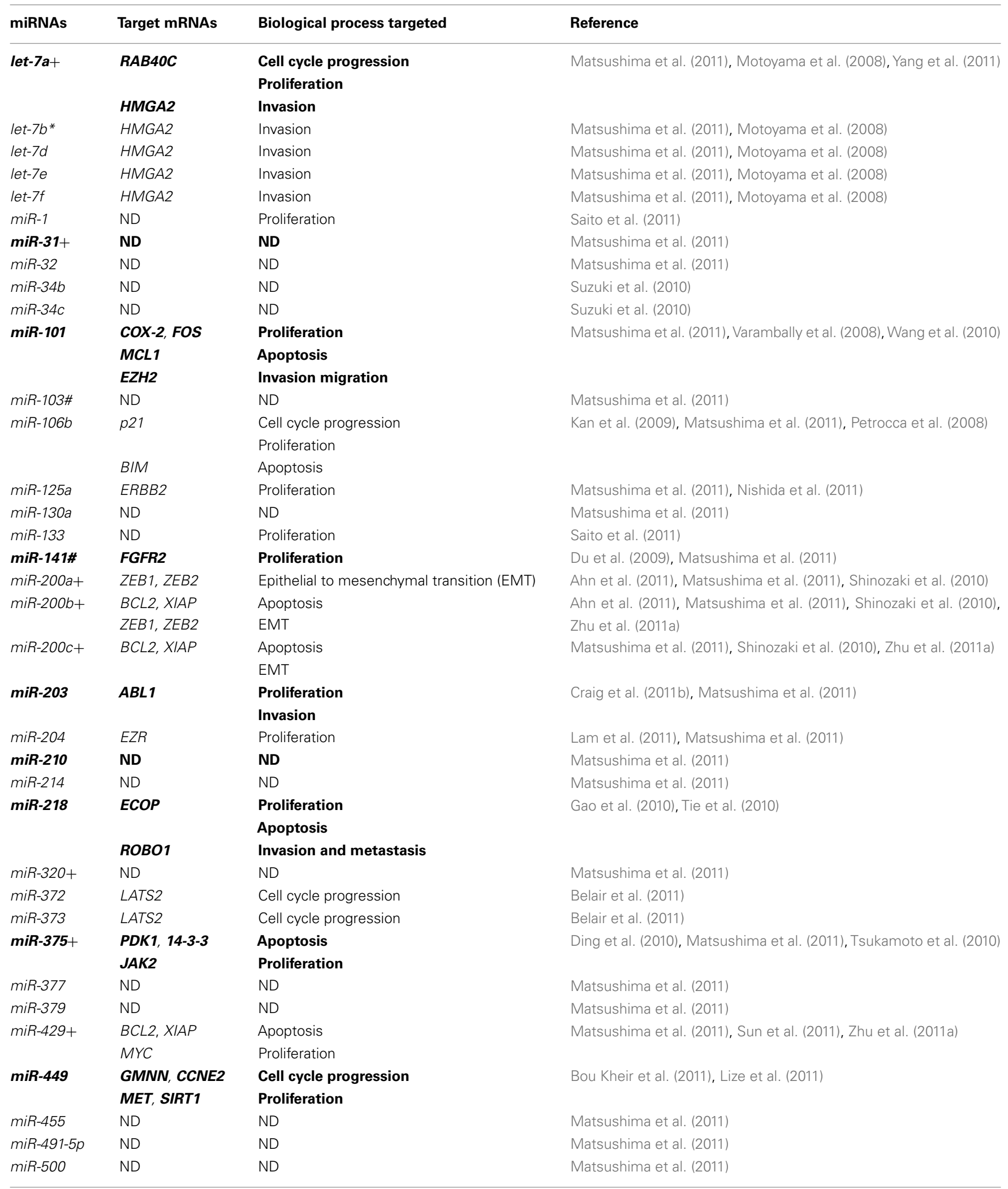


Table 1 | Continued

\begin{tabular}{llll}
\hline miRNAs & Target mRNAs & Biological process targeted & Reference \\
\hline miR-532\# & ND & ND & Matsushima et al. (2011) \\
miR-652\# & ND & ND & Matsushima et al. (2011)
\end{tabular}

Target criteria included (1) reduced protein expression upon miRNA transfection in gastric cells or expression inversely correlated with miRNA in gastric tissue or (2) presence of miRNA binding site on the 3UTR of target mRNA confirmed by luciferase reporter assay. ND, target mRNA or biological process not determined. *, miRNA expression correlates with acute inflammation. \#, miRNA expression correlates with chronic inflammation. +, miRNA expression correlates with both acute and chronic inflammation. Bold indicates miRNA also downregulated in gastric cancer.

Table 2 | miRNAs upregulated in response to $H$. pylori infection.

\begin{tabular}{|c|c|c|c|}
\hline miRNAs & Target mRNAs & Biological process targeted & Reference \\
\hline $\operatorname{miR}-17^{\wedge}$ & $p 21$ & Cell cycle progression & Saito et al. (2010) \\
\hline $\operatorname{miR}-20 a^{\wedge}$ & $p 21$ & Cell cycle progression & Saito et al. (2010) \\
\hline \multirow{2}{*}{ miR-21 } & RECK & Apoptosis & \\
\hline & PTEN & Invasion & \\
\hline miR-146a & SMAD4 & Apoptosis & \\
\hline \multirow[t]{2}{*}{$\operatorname{miR-155}$} & $I K K-\varepsilon, S M A D 2$ & Immune response & Fassi Fehri et al. (2010), Oertli et al. (2011), Tang et al. (2010), Xiao et al. (2009b) \\
\hline & FADD, PKI $\alpha$ & Apoptosis & \\
\hline $\operatorname{miR}-223 *$ & EPB41L3 & Invasion and metastasis & Li et al. (2011 b), Matsushima et al. (2011) \\
\hline
\end{tabular}

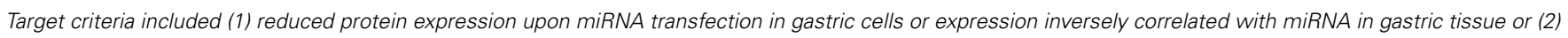

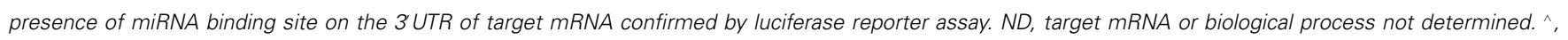

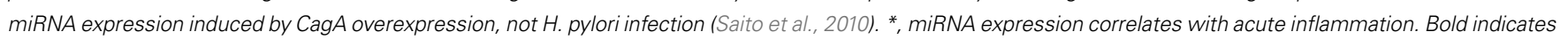
miRNA also upregulated in gastric cancer.

\section{HELICOBACTER PYLORI AND MIRNAS REGULATE CELL CYCLE PROGRESSION}

Disruption of cell cycle progression and increased cellular proliferation are common features of malignancies. Cell cycle progression requires coordinated expression of cyclins, which results in sequential activation of cyclin-dependent kinases (CDKs). miRNA dysregulation promotes cell cycle progression by upregulating cyclin expression and/or downregulating expression of CDK inhibitors (p15, p16, p18, p19, p21, p27, p28, p57) in various cancers, including gastric cancer (Figure 3). $m i R-449$, a miRNA downregulated in $H$. pylori-infected gastric tissue and in gastric cancer, targets GMNN (geminin) and CCNE2 (cyclin E2; Figure 3). Both geminin and cyclin E2 are overexpressed in numerous malignancies and promote M/G1 and G1/Scell cycle progression and cell proliferation (Bou Kheir et al., 2011; Lize et al., 2011). Consequently, downregulation of $m i R-449$, as occurs following $H$. pylori infection, promotes cell cycle progression and proliferation through upregulation of geminin and cyclin E2.

$\mathrm{p} 42.3$, a recently identified protein significantly upregulated in gastric cancer, regulates $\mathrm{G} 2 / \mathrm{M}$ cell cycle progression and proliferation in gastric cancer cells (Xu et al., 2007). miR-29a, a miRNA significantly downregulated in gastric cancer, targets $p 42.3$ (Cui et al., 2011; Figure 3). Thus, the downregulation of $m i R-29 a$ results in a reciprocal increase in $\mathrm{p} 42.3$ expression, promoting increased cell cycle progression and proliferation.
The retinoblastoma protein (RB1) is a tumor suppressor dysregulated in many cancers. $\mathrm{RB} 1$ functions to prevent excessive cell proliferation by inhibiting G1/S cell cycle progression. RB1 binds and inhibits transcription factors of the E2F family. When RB1 is bound to E2F the complex acts as a growth suppressor and prevents progression through cell cycle. A number of miRNAs target these factors. For instance, $m i R-106 a$ is upregulated in gastric cancer and targets RB1 (Volinia et al., 2006), while miR-331-3p is downregulated in gastric cancer and targets E2F1 (Guo et al., 2010; Figure 3).

TGF $\beta$ suppresses gastric cancer cell proliferation via the transcriptional upregulation of the CDK inhibitor, $p 21$ (Yoo et al., 1999). $m i R-93$ and $m i R-106 b$ directly target $p 21$, resulting in its transcriptional silencing and impairment of the tumorsuppressing activity of TGF $\beta$ (Petrocca et al., 2008; Kan et al., 2009; Figure 3). In addition, $m i R-25$ targets the CDK inhibitor, $p 57$, while $m i R-221$ and $m i R-222$ target the CDK inhibitors, $p 27$ and $p 57$ (Kim et al., 2009; Figure 3). These oncogenic miRNA clusters are also significantly upregulated in gastric cancer (Volinia et al., 2006; Petrocca et al., 2008; Guo et al., 2009; Kim et al., 2009; Yao et al., 2009). Overexpression of most of these miRNAs results in activation of CDK2, thereby promoting G1/S phase progression. Since numerous reports have described the role of $H$. pylori in the modulation of cyclins, CDKs, and CDK inhibitors and their link to gastric carcinogenesis (Shirin et al., 2001), these 


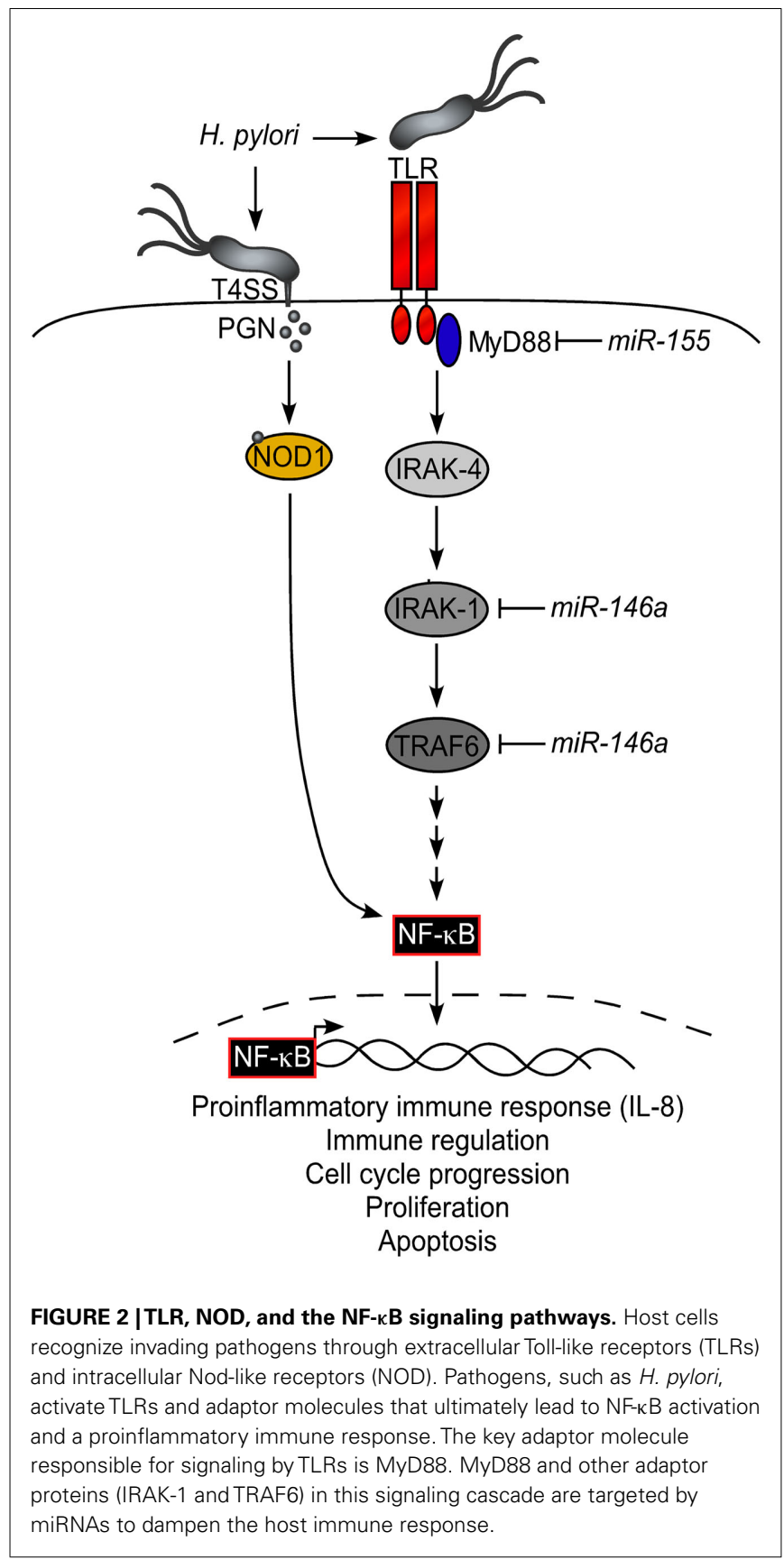

data suggest that $H$. pylori modulates expression of cyclins, CDKs, and CDK inhibitors through dysregulation of host miRNAs, which may increase the propensity for gastric transformation.

\section{HELICOBACTER PYLORI AND MIRNA DYSREGULATION INHIBIT APOPTOSIS AND PROMOTE CELL SURVIVAL}

Increased cellular proliferation and evasion of apoptosis are hallmarks of cellular transformation. Apoptosis can be classified as being dependent on either the intrinsic or extrinsic pathways. The intrinsic pathway is initiated within cells and hinges on the balance of activity between pro-apoptotic and anti-apoptotic members of the Bcl-2 (B cell lymphoma 2) superfamily of proteins, which

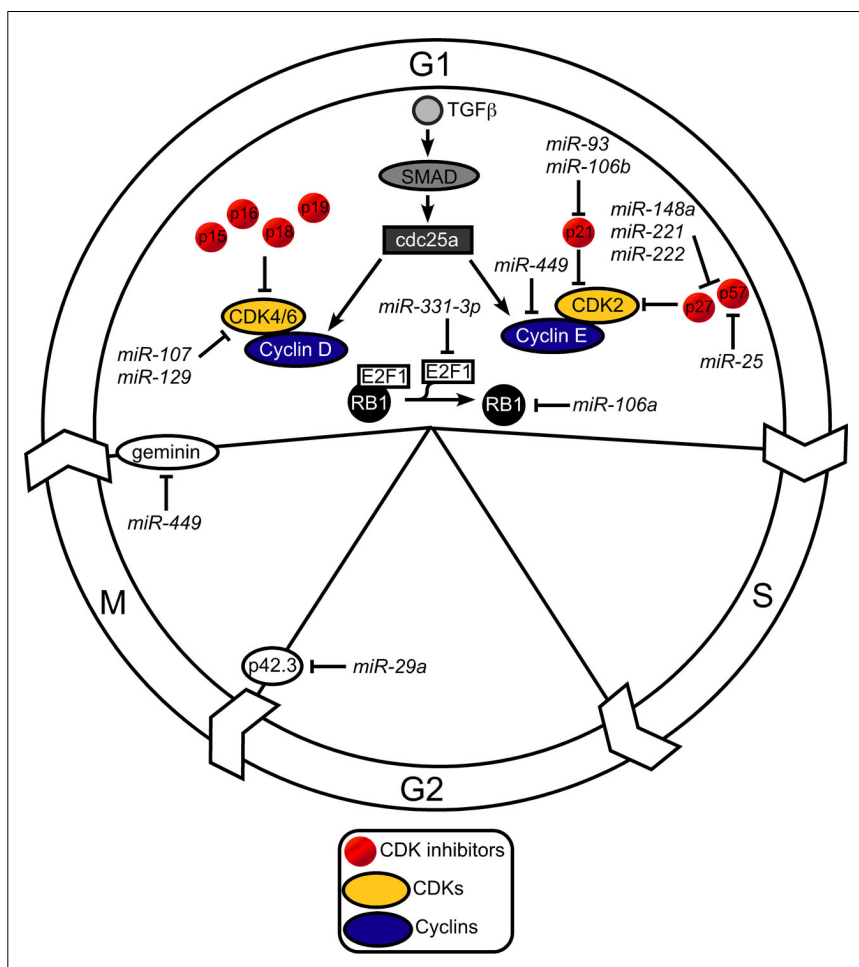

FIGURE 3 | Regulation of cell cycle progression. The cell cycle consists of four distinct phases: G1, S, G2, and M. Two key classes of regulatory molecules, cyclins and cyclin-dependent kinases (CDKs), determine a cells progress through the cell cycle. CDK inhibitors prevent the progression of cell cycle and function as tumor suppressors. miRNAs target the key regulatory molecules, cyclins and CDKs, as well as CDK inhibitors to disrupt normal cell cycle progression.

act to regulate the permeability of the mitochondrial membrane. miRNAs regulate apoptosis by altering expression and balance of members of the pro-apoptotic (e.g., Bax, Bak, Bim, Bad, Bid, and BNIP3L) and anti-apoptotic (e.g., Bcl-2, Bcl-xL, and Mcl-1) Bcl-2 protein family (Figure 4).

Numerous miRNAs overexpressed in gastric cancer function as oncomiRs by targeting members of the pro-apoptotic $\mathrm{Bcl}-2$ protein family. In addition to their role in regulating cell cycle progression, $m i R-25, m i R-93$, and $m i R-106 b$ also inhibit apoptosis by preventing expression of the pro-apoptotic protein, Bim (Kan et al., 2009; Figure 4). Overexpression of miR-130b also contributes to suppression of Bim and apoptosis by targeting RUNX3 (runt-related transcription factor; Lai et al., 2010), a known tumor suppressor frequently silenced in gastric cancer (Li et al., 2002). $m i R-150$ targets the EGR2 (early growth response protein; Wu et al., 2010), a tumor-suppressive transcription factor that induces apoptosis by direct transactivation of pro-apoptotic factors, Bak, and BNIP3L (Unoki and Nakamura, 2003).

Numerous tumor suppressor miRNAs target members of the anti-apoptotic $\mathrm{Bcl}-2$ protein family and are consequently downregulated in gastric cancer. $m i R-15 b, m i R-16, m i R-34, m i R-181 b$, $m i R-181 c$, and miR-497 directly target anti-apoptotic BCL2 (Ji et al., 2008; Xia et al., 2008; Zhu et al., 2010b, 2011b; Figure 4). These miRNA clusters are downregulated in gastric cancer cells 


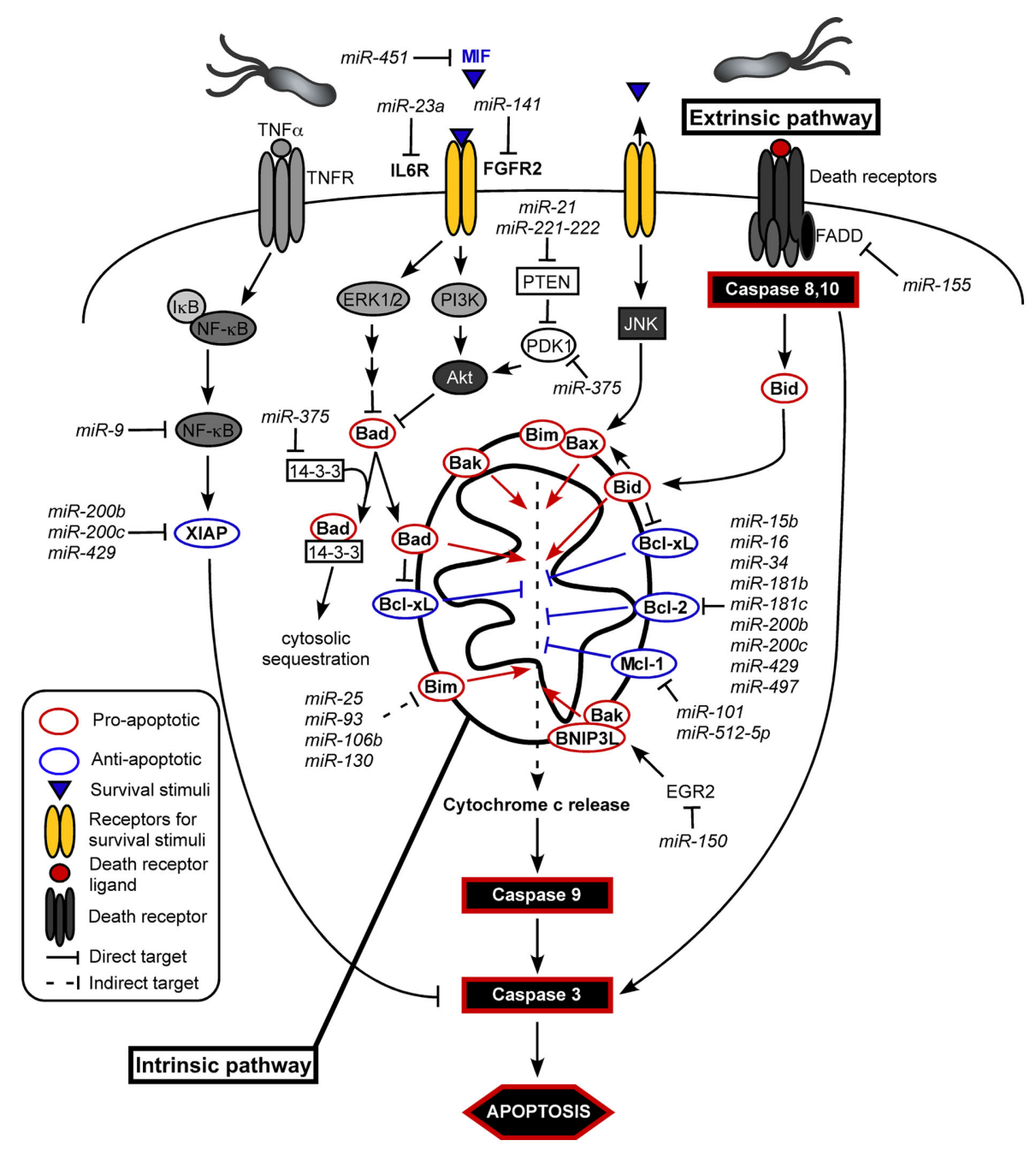

FIGURE 4 | Signaling cascades that regulate the intrinsic and extrinsic pathways of apoptosis. TNF $\alpha$ signaling leads to activation of NF- $\mathrm{B}$ and the anti-apoptotic protein XIAP. Other receptors that detect survival factors, such as growth factors and cytokines, induce ERK1/2 and PI3K/Akt signaling cascades that ultimately result in the inhibition of the pro-apoptotic protein, Bad. In contrast, upon removal of survival factors, these receptors can signal via JNK to induce the pro-apoptotic protein, Bax. Pro-apoptotic and anti-apoptotic proteins govern the intrinsic pathway of cell death, which results in the release of cytochrome $\mathrm{c}$ from the mitochondria and induction of the caspase cascade. Signaling through death receptors initiate the extrinsic pathway of apoptosis, leading to the induction of caspases and cell death. There are numerous miRNAs that regulate each of these pathways and dysregulation of these miRNAs can lead to anti-apoptotic and tumorigenic responses.
(Guo et al., 2009), leading to increased expression of Bcl-2 and inhibition of apoptosis. The $m i R-200 b c / 429$ cluster is downregulated in gastric cells, and these miRNAs directly target BCL2 and XIAP (x-linked inhibitor of apoptosis), leading to reduced expression and increased apoptosis (Zhu et al., 2011a; Figure 4). $m i R-101$ and $m i R-512-5 p$ target another anti-apoptotic member of the Bcl-2 family, MCL1 (myeloid leukemia cell differentiation protein; Saito et al., 2009; Wang et al., 2010; Figure 4). Both miR101 and $m i R-512-5 p$ are downregulated in gastric cancer, leading to increased levels of Mcl-1 and an anti-apoptotic phenotype. In addition, miR-101 is downregulated by H. pylori (Matsushima et al., 2011). miR-449 is also likely involved in mediating the intrinsic pathway of apoptosis and has been classified as a potent inducer of cell cycle arrest and cell death. miR-449 expression is reduced in
H. pylori-infected gastric tissue, and its expression is lost in gastric tumors (Bou Kheir et al., 2011; Lize et al., 2011). Conversely, overexpression of $m i R-449$ inhibits cellular proliferation and induces significant levels of apoptosis, and since $m i R-449$ belongs to the family of p53-responsive miRNAs, its overexpression also results in activation of p53 and apoptosis-specific marker, caspase 3.

In contrast to the intrinsic pathway, the extrinsic pathway of apoptosis is initiated on the cell surface through the activation of specific pro-apoptotic, death receptors. Specific pro-apoptotic ligands are known to activate the extrinsic pathway of apoptosis via specific receptor binding. Ligand binding induces receptor clustering and the recruitment of the adaptor protein Fas-associated death domain (FADD), leading to induction of caspases and ultimately cell death. In addition to its role in regulating the host 
immune response, $m i R-155$ targets FADD (Figure 4), leading to decreased expression of this key adaptor molecule (Xiao et al., 2009b). Therefore, the upregulation of $m i R-155$ by H. pylori and during carcinogenesis results in downregulation of FADD and inhibition of apoptosis.

In addition to targeting proteins directly involved in the intrinsic and extrinsic pathways of cell death, miRNAs target other factors that ultimately lead to inhibition of apoptosis and increased proliferation. $m i R-375$ targets $14-3-3$ zeta, an anti-apoptotic protein that mediates cell survival by binding the pro-apoptotic protein Bad and sequestering it to the cytosol (Tsukamoto et al., 2010; Figure 4). miR-375 also targets PDK1 (3-phosphoinositide dependent protein kinase), a kinase that directly phosphorylates Akt, thereby regulating the PI3K/Akt signaling pathway (Figure 4). Overexpression of $m i R-375$ was shown to substantially reduce cell viability through induction of the caspase-dependent apoptotic pathway. miR-375 is one of the most highly downregulated miRNAs in gastric cancer (Tsukamoto et al., 2010), suggesting its role as a potent tumor suppressor that contributes to the development of gastric carcinoma.

In contrast, $m i R-21$, a known oncomir that targets many known tumor suppressors, is consistently upregulated in various human cancers, including gastric cancer (Volinia et al., 2006; Chan et al., 2008; Petrocca et al., 2008; Zhang et al., 2008; Guo et al., 2009), and $m i R-21$ expression is increased in $H$. pylori-infected gastric tissues (Zhang et al., 2008). Overexpression of $m i R-21$ shifts the balance between proliferation and apoptosis, increasing cellular proliferation and inhibiting apoptosis. Specifically, $m i R-21$ targets PTEN (phosphatase and tensin homolog), a tumor suppressor and negative regulator of the PI3K/Akt signaling pathway (Yamanaka et al., 2009), which is involved in both apoptotic and proliferative pathways (Figure 4). Mutations in PTEN are important in the progression of many cancers, including gastric carcinoma (Kang et al., 2002). miR-21 likely also contributes to apoptosis by targeting PDCD4 (programmed cell death protein 4), which is localized to the nucleus of proliferating cells; however, its direct role in apoptosis has not been elucidated (Lu et al., 2008; Motoyama et al., 2010).

Similar to PI3K/Akt signaling, the NF- $\mathrm{B}$ signaling pathway is important in inhibition of apoptosis and cell survival. The NF- $\kappa$ B signaling cascade is activated during $H$. pylori-induced gastritis and is constitutively active in gastric cancer (Sasaki et al., 2001). $m i R-218$ expression is reduced in numerous cancers, including gastric cancer. $H$. pylori infection also reduces the expression of $m i R-218$ in vitro and in vivo. $m i R-218$ induces apoptosis in gastric cancer cells through direct targeting of ECOP (epidermal growth factor receptor-co-amplified and overexpressed protein), a known positive regulator of NF- $\kappa B$ transcriptional activity. Downregulation of $m i R-218$ leads to overexpression of ECOP, inhibition of NF- $\kappa \mathrm{B}$ transcriptional activation, and transcription of a downstream target COX-2, ultimately inhibiting apoptosis, and inducing cell proliferation (Gao et al., 2010). Another miRNA important in regulating NF- $\kappa \mathrm{B}$ signal transduction pathways is $m i R-9$, which directly targets $N F-\kappa B 1$, thereby suppressing NF$\kappa \mathrm{B}$ transcriptional activity (Figure 4). miR-9 is downregulated in gastric cancer and in vitro studies have shown that restoration of miR-9 expression suppresses proliferation of gastric cancer cells (Luo et al., 2009; Wan et al., 2010). Cumulatively, these studies demonstrate that aberrant activation of NF- $\kappa \mathrm{B}$ signaling as a result of $H$. pylori-induced miRNA dysregulation results in inhibition of apoptosis and increased proliferation, thereby sensitizing cells for subsequent mutagenesis.

miR-451, another downregulated miRNA in H. pylori-infected gastric mucosa and gastric cancer, targets MIF (macrophage migration inhibitory factor; Bandres et al., 2009), a lymphokine involved in cell-mediated immunity that is expressed in response to $H$. pylori infection and during gastric carcinogenesis (He et al., 2006). Overexpression of $m i R-451$ results in targeted downregulation of MIF, which is accompanied by a decrease in cell proliferation and increased apoptosis (Figure 4). Furthermore, there is an inverse correlation between $m i R-451$ and MIF expression in gastric cancer, suggesting that $m i R-451$ functions as a tumor suppressor by silencing MIF expression, leading to a proliferative and anti-apoptotic phenotype (Bandres et al., 2009). miR-141, another miRNA significantly decreased in $H$. pylori-infected gastric tissue (Matsushima et al., 2011) as well as gastric carcinoma, targets FGFR2 (fibroblast growth factor receptor), and overexpression of miR-141 leads to decreased FGFR2 expression and inhibition of proliferation (Du et al., 2009; Figure 4). miR-23a functions as a growth-promoting and anti-apoptotic factor. It is significantly upregulated in gastric adenocarcinoma and targets $I L-6 R$ (interleukin-6 receptor), which promotes increased proliferation and decreased apoptosis in gastric adenocarcinoma cells (Zhu et al., 2010a; Figure 4).

\section{HELICOBACTER PYLORI AND MIRNA DYSREGULATION PROMOTES CELL INVASION AND METASTASIS}

Invasion and metastasis are hallmarks of cancer cells. Several intracellular signaling pathways, such as those mediated by TGF $\beta$ and hepatocyte growth factor/Met signaling, promote metastasis. In addition to its role in regulating cell cycle progression, the $H$. pylori downregulated $m i R-449$ also targets $M e t$, a known proto-oncogene that encodes the hepatocyte growth factor receptor. Aberrant activation of Met triggers oncogenic processes, such as proliferation, angiogenesis, invasion, and metastasis (Bou Kheir et al., 2011; Lize et al., 2011). Thus, the targeted downregulation of $m i R-449$ by $H$. pylori and during gastric carcinogenesis results in upregulation of Met, increased cell proliferation, and likely other oncogenic processes.

The metastatic potential of cancer cells is also regulated by mechanisms that control cell survival, cytoskeletal changes, as well as the activity of extracellular matrix-degrading proteinases (MMPs). Many miRNAs known to regulate cell cycle progression, proliferation, and apoptosis pathways are also involved in metastasis. For example, overexpression of $m i R-21$ has been shown to increase the invasiveness of gastric cancer cells. In addition to its known tumor suppressor targets, $m i R-21$ also targets $R E C K$ (reversion-inducing-cysteine-rich protein with kazal motifs), a tumor and metastasis suppressor that inhibits tumor metastasis and angiogenesis through modulation of matrix metalloproteinases (MMPs; Zhang et al., 2008). H. pylori induces expression of MMPs, including MMP-1, MMP-2, MMP-3, MMP-7, MMP-9, which have been linked to $H$. pylori-induced disease and carcinogenesis (Elkington et al., 2005). These data suggest that $H$. pylori has the potential to modulate expression of MMPs through 
dysregulation of host miRNAs and these disruptions may increase the propensity for gastric transformation.

miR-106a is significantly upregulated in cancer cells (Volinia et al., 2006) and is known to correlate with increased lymphatic and distant metastasis (Xiao et al., 2009a). Conversely, miR-218, a tumor suppressor miRNA, is downregulated in gastric cancer (Volinia et al., 2006), which correlates with increased metastasis and invasion. This is thought to occur through direct targeting of $\mathrm{ROBO} 1$ (roundabout homolog), which leads to enhanced signaling through the ROBO1 receptor. The SLIT/ROBO signaling pathway has been implicated in many biological responses through regulation of cell migration (Tie et al., 2010). Thus, disruption of this signaling cascade can result in increased invasion and metastasis.

\section{CONCLUSION}

The discovery of miRNAs just over a decade ago has challenged the central dogma of genetic and epigenetic regulation. Although extensive work has been dedicated to identifying miRNAs, mRNA targets, and their contribution to accepted regulatory networks, we have only begun to scratch the surface. With thousands of miRNAs within the human genome, and the ability of each miRNA to target and regulate numerous protein-coding mRNAs, affected regulatory networks are likely to be modified by countless miRNA contributors and will continue to evolve.

Many questions arise when comparing miRNA expression profiles in different model systems in vitro and in vivo and when comparing miRNA expression profiles in $H$. pylori-infected gastric tissue and gastric cancer. For example, miR-106b, a known oncogenic miRNA, upregulated in various malignancies including gastric cancer, is decreased in $H$. pylori-infected gastric mucosa.

\section{REFERENCES}

Ahn, S. M., Cha, J. Y., Kim, J., Kim, D., Trang, H. T., Kim, Y. M., Cho, Y. H., Park, D., and Hong, S. (2011). Smad3 regulates E-cadherin via miRNA-200 pathway. Oncogene. doi: 10.1038/onc.2011.484. [Epub ahead of print].

Akopyants, N. S., Clifton, S. W., Kersulyte, D., Crabtree, J. E., Youree, B. E., Reece, C. A., Bukanov, N. O., Drazek, E. S., Roe, B. A., and Berg, D. E. (1998). Analyses of the cag pathogenicity island of Helicobacter pylori. Mol. Microbiol. 28, 37-53.

Alm, R. A., Ling, L. S., Moir, D. T., King, B. L., Brown, E. D., Doig, P. C., Smith, D. R., Noonan, B., Guild, B. C., deJonge, B. L., Carmel, G., Tummino, P. J., Caruso, A., Uria-Nickelsen, M., Mills, D. M., Ives, C., Gibson, R., Merberg, D., Mills, S. D., Jiang, Q., Taylor, D. E., Vovis, G. F., and Trust, T. J. (1999). Genomic-sequence comparison of two unrelated isolates of the human gastric pathogen Helicobacter pylori. Nature 397, 176-180.
Ambros, V. (2004). The functions of animal microRNAs. Nature 431, 350-355. Agorreta, J., Fortes, P., Agirre, X., Zarate, R., Diaz-Gonzalez, J. A., Ramirez, N., Sola, J. J., Jimenez, P., Rodriguez, J., and GarciaFoncillas, J. (2009). microRNA451 regulates macrophage migration inhibitory factor production and proliferation of gastrointestinal cancer cells. Clin. Cancer Res. 15, 2281-2290.

Bartel, D. P. (2009). microRNAs: target recognition and regulatory functions. Cell 136, 215-233.

Belair, C., Baud, J., Chabas, S., Sharma, C. M., Vogel, J., Staedel, C., and Darfeuille, F. (2011). Helicobacter pylori interferes with an embryonic stem cell micro RNA cluster to block cell cycle progression. Silence 2, 7-23.

Boncristiano, M., Paccani, S. R., Barone, S., Ulivieri, C., Patrussi, L., Ilver, D., Amedei, A., D’Elios, M. M., Telford, J. L., and Baldari, C. T. (2003). The Helicobacter pylori vacuolating toxin inhibits
Bandres, E., Bitarte, N., Arias, F.,

Similarly, miR-34b, miR-34c, miR-103, miR-200a, miR-200b, miR214 , and $m i R-372$ are all overexpressed in gastric cancer, while in H. pylori-infected gastric mucosa these miRNAs are significantly downregulated. In contrast, $m i R-146 a$ is significantly decreased in gastric cancer, but upregulated in $H$. pylori-infected gastric tissue. However, a recent report has shown that miR-146a is upregulated in a subset of gastric cancers. Although examining miRNA expression signatures in gastric cancer is clearly important in understanding the disease, development of novel therapeutics requires greater insight into the miRNA profiles in precancerous gastric tissues. Since the majority of gastric cancers arise within the context of chronic inflammation, it will be particularly important to discriminate between preneoplastic and tumor-specific miRNA expression profiles. A more comprehensive understanding of the roles of miRNAs in normal biological processes and disease is needed to fully appreciate miRNA dysregulation by pathogens, such as $H$. pylori. Furthermore, the relationship between single miRNAs and their targets are important to consider, but many of these relationships are cell and context specific. Thus, it is critically important to dissect these intricate pathways and understand how host-pathogen interactions disrupt these encompassing regulatory pathways.

\section{ACKNOWLEDGMENTS}

We would like to acknowledge James Patton from Vanderbilt University for his expertise and guidance in the subject matter of miRNAs. We would like to acknowledge the following funding sources through National Institutes of Health: NCI F32CA153539 (Jennifer M. Noto), NCI P01CA116087 (Richard M. Peek), NCI R01CA077955 (Richard M. Peek), NIDDK R01DK058587 (Richard M. Peek), and NIDDK P30DK058404 (Richard M. Peek).

$\mathrm{T}$ cell activation by two independent mechanisms. J. Exp. Med. 198, 1887-1897.

Bou Kheir, T., Futoma-Kazmierczak, E., Jacobsen, A., Krogh, A., Bardram, L., Hother, C., Gronbaek, K., Federspiel, B., Lund, A. H., and Friis-Hansen, L. (2011). miR-449 inhibits cell proliferation and is down-regulated in gastric cancer. Mol. Cancer 10, 29-40.

Censini, S., Lange, C., Xiang, Z., Crabtree, J. E., Ghiara, P., Borodovsky, M., Rappuoli, R., and Covacci, A. (1996). cag, a pathogenicity island of Helicobacter pylori, encodes type I- specific and disease-associated virulence factors. Proc. Natl. Acad. Sci. U.S.A. 93, 14648-14653.

Chan, S. H., Wu, C. W., Li, A. F., Chi, C. W., and Lin, W. C. (2008). miR21 microRNA expression in human gastric carcinomas and its clinical association. Anticancer Res. 28, 907-911.

Chen, C. Z., Li, L., Lodish, H. F., and Bartel, D. P. (2004). microRNAs modulate hematopoietic lineage differentiation. Science 303, 83-86.
Costinean, S., Zanesi, N., Pekarsky, Y., Tili, E., Volinia, S., Heerema, N., and Croce, C. M. (2006). Pre-B cell proliferation and lymphoblastic leukemia/high-grade lymphoma in $\mathrm{E}(\mathrm{mu})$-miR155 transgenic mice. Proc. Natl. Acad. Sci. U.S.A. 103, 7024-7029.

Covacci, A., Censini, S., Bugnoli, M., Petracca, R., Burroni, D., Macchia, G., Massone, A., Papini, E., Xiang, Z., Figura, N., and Rappuoli, R. (1993). Molecular characterization of the $128-\mathrm{kDa}$ immunodominant antigen of Helicobacter pylori associated with cytotoxicity and duodenal ulcer. Proc. Natl. Acad. Sci. U.S.A. 90, 5791-5795.

Cover, T. L., and Blaser, M. J. (1992). Purification and characterization of the vacuolating toxin from Helicobacter pylori. J. Biol. Chem. 267, 10570-10575.

Cover, T. L., Tummuru, M. K., Cao, P., Thompson, S. A., and Blaser, M. J. (1994). Divergence of genetic sequences for the vacuolating cytotoxin among Helicobacter pylori strains. J. Biol. Chem. 269, 10566-10573. 
Craig, V. J., Cogliatti, S. B., Imig, J., Renner, C., Neuenschwander, S., Rehrauer, H., Schlapbach, R., Dirnhofer, S., Tzankov, A., and Muller, A. (2011a). Myc-mediated repression of microRNA-34a promotes highgrade transformation of B-cell lymphoma by dysregulation of FoxP1. Blood 117, 6227-6236.

Craig, V. J., Cogliatti, S. B., Rehrauer, H., Wundisch, T., and Muller, A. (2011b). Epigenetic silencing of microRNA-203 dysregulates ABL1 expression and drives Helicobacterassociated gastric lymphomagenesis. Cancer Res. 71, 3616-3624.

Cui, Y., Su, W. Y., Xing, J., Wang, Y. C., Wang, P., Chen, X. Y., Shen, Z. Y., Cao, H., Lu, Y. Y., and Fang, J. Y. (2011). miR-29a inhibits cell proliferation and induces cell cycle arrest through the downregulation of $\mathrm{p} 42.3$ in human gastric cancer. PLoS ONE 6, e25872. doi:10.1371/journal.pone.0025872

Ding, L., Xu, Y., Zhang, W., Deng, Y., Si, M., Du, Y., Yao, H., Liu, X., Ke, Y., Si, J., and Zhou, T. (2010). miR-375 frequently downregulated in gastric cancer inhibits cell proliferation by targeting JAK2. Cell Res. 20, 784-793.

Du, Y., Xu, Y., Ding, L., Yao, H., Yu, H., Zhou, T., and Si, J. (2009). Down-regulation of miR-141 in gastric cancer and its involvement in cell growth. J. Gastroenterol. 44, 556-561.

Elkington, P. T., O'Kane, C. M., and Friedland, J. S. (2005). The paradox of matrix metalloproteinases in infectious disease. Clin. Exp. Immunol. 142, 12-20.

El-Omar, E. M., Carrington, M., Chow, W. H., McColl, K. E., Bream, J. H., Young, H. A., Herrera, J., Lissowska, J., Yuan, C. C., Rothman, N., Lanyon, G., Martin, M., Fraumeni, J. F. Jr., and Rabkin, C. S. (2000). Interleukin-1 polymorphisms associated with increased risk of gastric cancer. Nature 404, 398-402.

El-Omar, E. M., Rabkin, C. S., Gammon, M. D., Vaughan, T. L., Risch, H. A., Schoenberg, J. B., Stanford, J. L., Mayne, S. T., Goedert, J., Blot, W. J., Fraumeni, J. F. Jr., and Chow, W. H. (2003). Increased risk of noncardia gastric cancer associated with proinflammatory cytokine gene polymorphisms. Gastroenterology 124, 1193-1201.

Fassi Fehri, L., Koch, M., Belogolova, E., Khalil, H., Bolz, C., Kalali, B., Mollenkopf, H. J., Beigier-Bompadre, M., Karlas, A., Schneider, T., Churin, Y., Gerhard, M., and Meyer, T. F. (2010). Helicobacter pylori induces
miR-155 in $\mathrm{T}$ cells in a cAMPFoxp3-dependent manner. PLoS ONE 5, e9500. doi:10.1371/journal.pone.0009500

Ferlay, J., Autier, P., Boniol, M., Heanue, M., Colombet, M., and Boyle, P. (2007). Estimates of the cancer incidence and mortality in Europe in 2006. Ann. Oncol. 18, 581-592.

Figueiredo, C., Machado, J. C., Pharoah, P., Seruca, R., Sousa, S., Carvalho, R., Capelinha, A. F., Quint, W., Caldas, C., van Doorn, L. J., Carneiro, F., and Sobrinho-Simoes, M. (2002). Helicobacter pylori and interleukin 1 genotyping: an opportunity to identify high-risk individuals for gastric carcinoma. J. Natl. Cancer Inst. 94, 1680-1687.

Fu, S., Ramanujam, K. S., Wong, A., Fantry, G. T., Drachenberg, C. B., James, S. P., Meltzer, S. J., and Wilson, K. T. (1999). Increased expression and cellular localization of inducible nitric oxide synthase and cyclooxygenase 2 in Helicobacter pylori gastritis. Gastroenterology 116, 1319-1329.

Furuta, T., El-Omar, E. M., Xiao, F., Shirai, N., Takashima, M., and Sugimurra, H. (2002). Interleukin lbeta polymorphisms increase risk of hypochlorhydria and atrophic gastritis and reduce risk of duodenal ulcer recurrence in Japan. Gastroenterology 123, 92-105.

Gao, C., Zhang, Z., Liu, W., Xiao, S., $\mathrm{Gu}$, W., and Lu, H. (2010). Reduced microRNA-218 expression is associated with high nuclear factor kappa $B$ activation in gastric cancer. Cancer 116, 41-49.

Gebert, B., Fischer, W., Weiss, E., Hoffmann, R., and Haas, R. (2003). Helicobacter pylori vacuolating cytotoxin inhibits $\mathrm{T}$ lymphocyte activation. Science 301, 1099-1102.

Gerhard, M., Lehn, N., Neumayer, N., Boren, T., Rad, R., Schepp, W., Miehlke, S., Classen, M., and Prinz, C. (1999). Clinical relevance of the Helicobacter pylori gene for blood-group antigen-binding adhesin. Proc. Natl. Acad. Sci. U.S.A. 96, 12778-12783.

Goodwin, C. S., Armstrong, J. A., and Marshall, B. J. (1986). Campylobacter pyloridis, gastritis, and peptic ulceration. J. Clin. Pathol. 39, 353-365.

Guo, J., Miao, Y., Xiao, B., Huan, R., Jiang, Z., Meng, D., and Wang, Y. (2009). Differential expression of microRNA species in human gastric cancer versus non-tumorous tissues. J. Gastroenterol. Hepatol. 24, 652-657.

Guo, X., Guo, L., Ji, J., Zhang, J., Chen, X., Cai, Q., Li, J., Gu, Q., Liu, B., Zhu,
Z., and Yu, Y. (2010). miRNA-3313 p directly targets E2F1 and induces growth arrest in human gastric cancer. Biochem. Biophys. Res. Commun. 398, 1-6.

He, X. X., Yang, J., Ding, Y. W., Liu, W., Shen, Q. Y., and Xia, H. H. (2006). Increased epithelial and serum expression of macrophage migration inhibitory factor (MIF) in gastric cancer: potential role of MIF in gastric carcinogenesis. Gut 55, 797-802.

Hessey, S. J., Spencer, J., Wyatt, J. I., Sobala, G., Rathbone, B. J., Axon, A. T., and Dixon, M. F. (1990). Bacterial adhesion and disease activity in Helicobacter associated chronic gastritis. Gut 31, 134-138.

Ilver, D., Arnqvist, A., Ogren, J., Frick, I. M., Kersulyte, D., Incecik, E. T., Berg, D. E., Covacci, A., Engstrand, L., and Boren, T. (1998). Helicobacter pylori adhesin binding fucosylated histo-blood group antigens revealed by retagging. Science 279, 373-377.

Ji, Q., Hao, X., Meng, Y., Zhang, M., Desano, J., Fan, D., and Xu, L. (2008). Restoration of tumor suppressor miR-34 inhibits human p53-mutant gastric cancer tumorspheres. BMC Cancer 8, 266-277. doi:10.1186/1471-2407-8-266

Juttner, S., Cramer, T., Wessler, S., Walduck, A., Gao, F., Schmitz, F., Wunder, C., Weber, M., Fischer, S. M., Schmidt, W. E. Wiedenmann, B., Meyer, T. F., Naumann, M., and Hocker, M. (2003). Helicobacter pylori stimulates host cyclooxygenase-2 gene transcription: critical importance of MEK/ERK-dependent activation of USF1/-2 and CREB transcription factors. Cell. Microbiol. 5, 821-834.

Kan, T., Sato, F., Ito, T., Matsumura, N., David, S., Cheng, Y., Agarwal, R., Paun, B. C., Jin, Z., Olaru, A. V., Selaru, F. M., Hamilton, J. P., Yang, J., Abraham, J. M., Mori, Y., and Meltzer, S. J. (2009). The miR-106b25 polycistron, activated by genomic amplification, functions as an oncogene by suppressing p21 and Bim. Gastroenterology 136, 1689-1700.

Kang, Y. H., Lee, H. S., and Kim, W. H. (2002). Promoter methylation and silencing of PTEN in gastric carcinoma. Lab. Invest. 82, 285-291.

Kim, Y. K., Yu, J., Han, T. S., Park, S. Y., Namkoong, B., Kim, D. H., Hur, K. Yoo, M. W., Lee, H. J., Yang, H. K., and Kim, V. N. (2009). Functional links between clustered microRNAs: suppression of cell-cycle inhibitors by microRNA clusters in gastric cancer. Nucleic Acids Res. 37, 1672-1681.
Kuck, D., Kolmerer, B., Iking-Konert, C., Krammer, P. H., Stremmel, W., and Rudi, J. (2001). Vacuolating cytotoxin of Helicobacter pylori induces apoptosis in the human gastric epithelial cell line AGS. Infect. Immun. 69, 5080-5087.

Lai, K. W., Koh, K. X., Loh, M., Tada, K., Subramaniam, M. M., Lim, X. Y., Vaithilingam, A., Salto-Tellez, M., Iacopetta, B., Ito, Y., and Soong, R. (2010). microRNA-130b regulates the tumour suppressor RUNX3 in gastric cancer. Eur. J. Cancer 46, 1456-1463.

Lam, E. K., Wang, X., Shin, V. Y., Zhang, S., Morrison, H., Sun, J., Ng, E. K., Yu, J., and Jin, H. (2011). A microRNA contribution to aberrant Ras activation in gastric cancer. Am. J. Transl. Res. 3, 209-218.

Lee, R. C., Feinbaum, R. L., and Ambros, V. (1993). The C. elegans heterochronic gene lin-4 encodes small RNAs with antisense complementarity to lin-14. Cell 75, 843-854.

Leunk, R. D., Johnson, P. T., David, B. C., Kraft, W. G., and Morgan, D. R. (1988). Cytotoxic activity in brothculture filtrates of Campylobacter pylori. J. Med. Microbiol. 26, 93-99.

Lewis, B. P., Shih, I. H., Jones-Rhoades, M. W., Bartel, D. P., and Burge, C. B. (2003). Prediction of mammalian microRNA targets. Cell 115, 787-798.

Li, N., Xu, X., Xiao, B., Zhu, E. D., Li, B. S., Liu, Z., Tang, B., Zou, Q. M., Liang, H. P., and Mao, X. H. (2011a). H. pylori related proinflammatory cytokines contribute to the induction of miR-146a in human gastric epithelial cells. Mol. Biol. Rep. doi 10.1007/s11033-011-1257-5. [Epub ahead of print]

Li, X., Zhang, Y., Zhang, H., Liu, X., Gong, T., Li, M., Sun, L., Ji, G., Shi, Y., Han, Z., Han, S., Nie, Y., Chen, X., Zhao, Q., Ding, J., Wu, K., and Daiming, F. (2011b). miRNA-223 promotes gastric cancer invasion and metastasis by targeting tumor suppressor EPB41L3. Mol. Cancer Res. 9, 824-833.

Li, Q. L., Ito, K., Sakakura, C., Fukamachi, H., Inoue, K., Chi, X. Z., Lee, K. Y., Nomura, S., Lee, C. W., Han, S. B., Kim, H. M., Kim, W. J., Yamamoto, H., Yamashita, N., Yano, T., Ikeda, T., Itohara, S., Inazawa, J., Abe, T., Hagiwara, A., Yamagishi, H., Ooe, A., Kaneda, A., Sugimura, T., Ushijima, T., Bae, S. C., and Ito, Y. (2002). Causal relationship between the loss of RUNX3 expression and gastric cancer. Cell 109, 113-124.

Liu, Z., Xiao, B., Tang, B., Li, B. Li, N., Zhu, E., Guo, G., Gu, J., 
Zhuang, Y., Liu, X., Ding, H., Zhao, X., Guo, H., Mao, X., and Zou, Q. (2010). Up-regulated microRNA146a negatively modulate Helicobacter pylori-induced inflammatory response in human gastric epithelial cells. Microbes Infect. 12, 854-863.

Lize, M., Klimke, A., and Dobbelstein, M. (2011). microRNA-449 in cell fate determination. Cell Cycle 10, 2874-2882.

Lu, J., Getz, G., Miska, E. A., AlvarezSaavedra, E., Lamb, J., Peck, D., Sweet-Cordero, A., Ebert, B. L., Mak, R. H., Ferrando, A. A., Downing, J. R., Jacks, T., Horvitz, H. R., and Golub, T. R. (2005). microRNA expression profiles classify human cancers. Nature 435, 834-838.

Lu, Z., Liu, M., Stribinskis, V., Klinge, C. M., Ramos, K. S., Colburn, N. H., and Li, Y. (2008). microRNA-21 promotes cell transformation by targeting the programmed cell death 4 gene. Oncogene 27, 4373-4379.

Luo, H., Zhang, H., Zhang, Z., Zhang, X., Ning, B., Guo, J., Nie, N., Liu, B., and Wu, X. (2009). Down-regulated miR-9 and miR-433 in human gastric carcinoma. J. Exp. Clin. Cancer Res. 28, 82-91.

Machado, J. C., Pharoah, P., Sousa, S., Carvalho, R., Oliveira, C., Figueiredo, C., Amorim, A., Seruca, R., Caldas, C., Carneiro, F., and Sobrinho-Simoes, M. (2001). Interleukin $1 \mathrm{~B}$ and interleukin $1 \mathrm{RN}$ polymorphisms are associated with increased risk of gastric carcinoma. Gastroenterology 121, 823-829.

Mahdavi, J., Sonden, B., Hurtig, M., Olfat, F. O., Forsberg, L., Roche, N., Angstrom, J., Larsson, T., Teneberg, S., Karlsson, K. A., Altraja, S., Wadstrom, T., Kersulyte, D., Berg, D. E., Dubois, A., Petersson, C., Magnusson, K. E., Norberg, T., Lindh, F., Lundskog, B. B., Arnqvist, A., Hammarstrom, L., and Boren, T. (2002). Helicobacter pylori SabA adhesin in persistent infection and chronic inflammation. Science 297, 573-578.

Marshall, B. J., Armstrong, J. A., McGechie, D. B., and Glancy, R. J. (1985). Attempt to fulfill Koch's postulates for pyloric Campylobacter. Med. J. Aust. 142, 436-439.

Matsushima, K., Isomoto, H., Inoue, N., Nakayama, T., Hayashi, T., Nakayama, M., Nakao, K., Hirayama, T., and Kohno, S. (2011). microRNA signatures in Helicobacter pyloriinfected gastric mucosa. Int. J. Cancer 128, 361-370.

McCarthy, C. J., Crofford, L. J., Greenson, J., and Scheiman, J. M. (1999). Cyclooxygenase-2 expression in gastric antral mucosa before and after eradication of Helicobacter pylori infection. Am. J. Gastroenterol. 94, 1218-1223.

Meyer, F., Ramanujam, K. S., Gobert, A. P., James, S. P., and Wilson, K. T. (2003). Cutting edge: cyclooxygenase- 2 activation suppresses Thl polarization in response to Helicobacter pylori. J. Immunol. 171, 3913-3917.

Motoyama, K., Inoue, H., Mimori, K., Tanaka, F., Kojima, K., Uetake, H., Sugihara, K., and Mori, M. (2010). Clinicopathological and prognostic significance of PDCD4 and microRNA-21 in human gastric cancer. Int. J. Oncol. 36, 1089-1095.

Motoyama, K., Inoue, H., Nakamura, Y., Uetake, H., Sugihara, K., and Mori, M. (2008). Clinical significance of high mobility group A2 in human gastric cancer and its relationship to let-7 microRNA family. Clin. Cancer Res. 14, 2334-2340.

Nishida, N., Mimori, K., Fabbri, M., Yokobori, T., Sudo, T., Tanaka, F., Shibata, K., Ishii, H., Doki, Y., and Mori, M. (2011). microRNA-125a-5p is an independent prognostic factor in gastric cancer and inhibits the proliferation of human gastric cancer cells in combination with trastuzumab. Clin. Cancer Res. 17, 2725-2733.

Oertli, M., Engler, D. B., Kohler, E., Koch, M., Meyer, T. F., and Muller, A. (2011). microRNA-155 is essential for the $\mathrm{T}$ cell-mediated control of Helicobacter pylori infection and for the induction of chronic gastritis and colitis. J. Immunol. 187, 3578-3586.

Okubo, M., Tahara, T., Shibata, T., Yamashita, H., Nakamura, M., Yoshioka, D., Yonemura, J., Ishizuka, T., Arisawa, T., and Hirata, I. (2010). Association between common genetic variants in premicroRNAs and gastric cancer risk in Japanese population. Helicobacter 15, 524-531.

Parkin, D. M. (2006). The global health burden of infection-associated cancers in the year 2002. Int. J. Cancer 118, 3030-3044.

Parkin, D. M., Bray, F., Ferlay, J., and Pisani, P. (2005). Global cancer statistics, 2002. CA Cancer J. Clin. 55, 74-108.

Petrocca, F., Visone, R., Onelli, M. R., Shah, M. H., Nicoloso, M. S., de Martino, I., Iliopoulos, D., Pilozzi, E., Liu, C. G., Negrini, M., Cavazzini, L., Volinia, S., Alder, H., Ruco, L. P., Baldassarre, G., Croce, C. M., and Vecchione, A. (2008). E2F1-regulated microRNAs impair TGFbeta-dependent cell-cycle arrest and apoptosis in gastric cancer. Cancer Cell 13, 272-286.

Phadnis, S. H., Ilver, D., Janzon, L., Normark, S., and Westblom, T. U. (1994). Pathological significance and molecular characterization of the vacuolating toxin gene of Helicobacter pylori. Infect. Immun. 62, 1557-1565.

Polk, D. B., and Peek, R. M. Jr. (2010). Helicobacter pylori: gastric cancer and beyond. Nat. Rev. Cancer 10 403-414.

Ristimaki, A., Honkanen, N., Jankala, H., Sipponen, P., and Harkonen, M. (1997). Expression of cyclooxygenase-2 in human gastric carcinoma. Cancer Res. 57, 1276-1280.

Romano, M., Ricci, V., Memoli, A., Tuccillo, C., Di Popolo, A., Sommi, P., Acquaviva, A. M., Del Vecchio Blanco, C., Bruni, C. B., and Zarrilli, R. (1998). Helicobacter pylori upregulates cyclooxygenase- 2 mRNA expression and prostaglandin E2 synthesis in MKN28 gastric mucosal cells in vitro. J. Biol. Chem. 273, 28560-28563.

Saito, Y., Murata-Kamiya, N., Hirayama, T., Ohba, Y., and Hatakeyama, M. (2010). Conversion of Helicobacter pylori CagA from senescence inducer to oncogenic driver through polarity-dependent regulation of p21. J. Exp. Med. 207, 2157-2174.

Saito, Y., Suzuki, H., Tsugawa, H., Nakagawa, I., Matsuzaki, J., Kanai, Y., and Hibi, T. (2009). Chromatin remodeling at Alu repeats by epigenetic treatment activates silenced microRNA512-5p with downregulation of Mcl1 in human gastric cancer cells. Oncogene 28, 2738-2744.

Saito, Y., Suzuki, H., Tsugawa, H., Suzuki, S., Matsuzaki, J., Hirata, K., and Hibi, T. (2011). Dysfunctional gastric emptying with down-regulation of muscle-specific microRNAs in Helicobacter pyloriinfected mice. Gastroenterology 140, 189-198.

Sasaki, N., Morisaki, T., Hashizume, K., Yao, T., Tsuneyoshi, M., Noshiro, H., Nakamura, K., Yamanaka, T., Uchiyama, A., Tanaka, M., and Katano, M. (2001). Nuclear factorkappaB p65 (RelA) transcription factor is constitutively activated in human gastric carcinoma tissue. Clin. Cancer Res. 7, 4136-4142.

Sawaoka, H., Kawano, S., Tsuji, S., Tsuji, M., Sun, W., Gunawan, E. S., and Hori, M. (1998). Helicobacter pylori infection induces cyclooxygenase2 expression in human gastric mucosa. Prostaglandins Leukot. Essent. Fatty Acids 59, 313-316.
Schmitt, W., and Haas, R. (1994). Genetic analysis of the Helicobacter pylori vacuolating cytotoxin: structural similarities with the IgA protease type of exported protein. Mol. Microbiol. 12, 307-319.

Shinozaki, A., Sakatani, T., Ushiku, T., Hino, R., Isogai, M., Ishikawa, S., Uozaki, H., Takada, K., and Fukayama, M. (2010). Downregulation of microRNA-200 in EBVassociated gastric carcinoma. Cancer Res. 70, 4719-4727.

Shirin, H., Weinstein, I. B., and Moss, S. F. (2001). Effects of H. pylori infection of gastric epithelial cells on cell cycle control. Front. Biosci. 6 , E104-E118.

Sonkoly, E., and Pivarcsi, A. (2009). Advances in microRNAs: implications for immunity and inflammatory diseases. J. Cell. Mol. Med. 13, 24-38.

Sun, T., Wang, C., Xing, J., and Wu, D. (2011). miR-429 modulates the expression of c-myc in human gastric carcinoma cells. Eur. J. Cancer. doi: 10.1016/j.ejca.2011.05.021. [Epub ahead of print].

Sundrud, M. S., Torres, V. J., Unutmaz, D., and Cover, T. L. (2004). Inhibition of primary human $\mathrm{T}$ cell proliferation by Helicobacter pylori vacuolating toxin (VacA) is independent of VacA effects on IL-2 secretion. Proc. Natl. Acad. Sci. U.S.A. 101, 7727-7732.

Sung, J. J., Leung, W. K., Go, M. Y., To, K. F., Cheng, A. S., Ng, E. K., and Chan, F. K. (2000). Cyclooxygenase2 expression in Helicobacter pyloriassociated premalignant and malignant gastric lesions. Am. J. Pathol. 157, 729-735.

Suzuki, H., Yamamoto, E., Nojima, M., Kai, M., Yamano, H. O., Yoshikawa, K., Kimura, T., Kudo, T., Harada, E., Sugai, T., Takamaru, H., Niinuma, T., Maruyama, R., Yamamoto, H., Tokino, T., Imai, K., Toyota, M., and Shinomura, Y. (2010). Methylation-associated silencing of microRNA-34b/c in gastric cancer and its involvement in an epigenetic field defect. Carcinogenesis 31, 2066-2073.

Tang, B., Xiao, B., Liu, Z., Li, N., Zhu, E. D., Li, B. S., Xie, Q. H., Zhuang, Y., Zou, Q. M., and Mao, X. H. (2010). Identification of MyD88 as a novel target of miR-155, involved in negative regulation of Helicobacter pylori-induced inflammation. FEBS Lett. 584, 1481-1486.

Telford, J. L., Ghiara, P., Dell'Orco, M., Comanducci, M., Burroni, D., Bugnoli, M., Tecce, M. F., Censini, S., Covacci, A., Xiang, Z., Papini, E., 
Montecucco, C., Parente, L., and Rappuoli, R. (1994). Gene structure of the Helicobacter pylori cytotoxin and evidence of its key role in gastric disease. J. Exp. Med. 179, 1653-1658.

Thai, T. H., Calado, D. P., Casola, S., Ansel, K. M., Xiao, C., Xue, Y., Murphy, A., Frendewey, D., Valenzuela, D., Kutok, J. L., Schmidt-Supprian, M., Rajewsky, N., Yancopoulos, G., Rao, A., and Rajewsky, K. (2007). Regulation of the germinal center response by microRNA-155. Science 316, 604-608.

Tie, J., Pan, Y., Zhao, L., Wu, K., Liu, J., Sun, S., Guo, X., Wang, B., Gang, Y., Zhang, Y., Li, Q., Qiao, T., Zhao, Q., Nie, Y., and Fan, D. (2010). miR-218 inhibits invasion and metastasis of gastric cancer by targeting the Robol receptor. PLoS Genet. 6, e1000879. doi:10.1371/journal.pgen.1000879

Tomb, J. F., White, O., Kerlavage, A. R., Clayton, R. A., Sutton, G. G., Fleischmann, R. D., Ketchum, K. A., Klenk, H. P., Gill, S., Dougherty, B. A., Nelson, K., Quackenbush, J., Zhou, L., Kirkness, E. F., Peterson, S., Loftus, B., Richardson, D., Dodson, R., Khalak, H. G., Glodek, A., McKenney, K., Fitzegerald, L. M., Lee, N., Adams, M. D., Hickey, E. K., Berg, D. E., Gocayne, J. D., Utterback, T. R., Peterson, J. D., Kelley, J. M., Cotton, M. D., Weidman, J. M., Fujii, C., Bowman, C., Watthey, L., Wallin, E., Hayes, W. S., Borodovsky, M., Karp, P. D., Smith, H. O., Fraser, C. M., and Venter, J. C. (1997). The complete genome sequence of the gastric pathogen Helicobacter pylori. Nature 388, 539-547.

Tsukamoto, Y., Nakada, C., Noguchi, T., Tanigawa, M., Nguyen, L. T., Uchida, T., Hijiya, N., Matsuura, K., Fujioka, T., Seto, M., and Moriyama, M. (2010). microRNA-375 is downregulated in gastric carcinomas and regulates cell survival by targeting PDK1 and 14-3-3zeta. Cancer Res. 70, 2339-2349.

Tummuru, M. K., Cover, T. L., and Blaser, M. J. (1993). Cloning and expression of a high-molecularmass major antigen of Helicobacter pylori: evidence of linkage to cytotoxin production. Infect. Immun. 61, 1799-1809.

Unoki, M., and Nakamura, Y. (2003). EGR2 induces apoptosis in various cancer cell lines by direct transactivation of BNIP3L and BAK. Oncogene 22, 2172-2185.

Varambally, S., Cao, Q., Mani, R. S., Shankar, S., Wang, X., Ateeq, B., Laxman, B., Cao, X., Jing, X., Ramnarayanan, K., Brenner, J. C., Yu,
J., Kim, J. H., Han, B., Tan, P., Kumar-Sinha, C., Lonigro, R. J., Palanisamy, N., Maher, C. A., and Chinnaiyan, A. M. (2008). Genomic loss of microRNA-101 leads to overexpression of histone methyltransferase EZH2 in cancer. Science 322, 1695-1699.

Viala, J., Chaput, C., Boneca, I. G., Cardona, A., Girardin, S. E., Moran, A. P., Athman, R., Memet, S., Huerre, M. R., Coyle, A. J., DiStefano, P. S., Sansonetti, P. J., Labigne, A., Bertin, J., Philpott, D. J., and Ferrero, R. L. (2004). Nod1 responds to peptidoglycan delivered by the Helicobacter pylori cag pathogenicity island. Nat. Immunol. 5, 1166-1174.

Volinia, S., Calin, G. A., Liu, C. G., Ambs, S., Cimmino, A., Petrocca, F., Visone, R., Iorio, M., Roldo, C., Ferracin, M., Prueitt, R. L., Yanaihara, N., Lanza, G., Scarpa, A., Vecchione, A., Negrini, M., Harris, C. C., and Croce, C. M. (2006). A microRNA expression signature of human solid tumors defines cancer gene targets. Proc. Natl. Acad. Sci. U.S.A. 103, 2257-2261.

Wan, H. Y., Guo, L. M., Liu, T., Liu, M., Li, X., and Tang, H. (2010). Regulation of the transcription factor NFkappaB1 by microRNA-9 in human gastric adenocarcinoma. Mol. Cancer $9,16$.

Wang, H. J., Ruan, H. J., He, X. J., Ma, Y. Y., Jiang, X. T., Xia, Y. J., Ye, Z. Y., and Tao, H. Q. (2010). microRNA101 is down-regulated in gastric cancer and involved in cell migration and invasion. Eur. J. Cancer 46, 2295-2303.

Wu, C. Y., Wang, C. J., Tseng, C. C., Chen, H. P., Wu, M. S., Lin, J. T., Inoue, H., and Chen, G. H. (2005). Helicobacter pylori promote gastric cancer cells invasion through a NF-kappaB and COX-2-mediated pathway. World J. Gastroenterol. 11, 3197-3203.

Wu, F., Zikusoka, M., Trindade, A., Dassopoulos, T., Harris, M. L., Bayless, T. M., Brant, S. R., Chakravarti, S., and Kwon, J. H. (2008). microRNAs are differentially expressed in ulcerative colitis and alter expression of macrophage inflammatory peptide-2 alpha. Gastroenterology 135, 1624-1635.e24.

Wu, Q., Jin, H., Yang, Z., Luo, G., Lu, Y., Li, K., Ren, G., Su, T., Pan, Y., Feng, B., Xue, Z., Wang, X., and Fan, D. (2010). miR-150 promotes gastric cancer proliferation by negatively regulating the pro-apoptotic gene EGR2. Biochem. Biophys. Res. Commun. 392, 340-345.
Xia, H. H., and Talley, N. J. (2001). Apoptosis in gastric epithelium induced by Helicobacter pylori infection: implications in gastric carcinogenesis. Am. J. Gastroenterol. 96, 16-26.

Xia, L., Zhang, D., Du, R., Pan, Y., Zhao, L., Sun, S., Hong, L., Liu, J., and Fan, D. (2008). miR-15b and miR16 modulate multidrug resistance by targeting BCL2 in human gastric cancer cells. Int. J. Cancer 123, 372-379.

Xiao, B., Guo, J., Miao, Y., Jiang, Z., Huan, R., Zhang, Y., Li, D., and Zhong, J. (2009a). Detection of miR-106a in gastric carcinoma and its clinical significance. Clin. Chim. Acta 400, 97-102.

Xiao, B., Liu, Z., Li, B. S., Tang, B., Li W., Guo, G., Shi, Y., Wang, F., Wu, Y., Tong, W. D., Guo, H., Mao, X. H., and Zou, Q. M. (2009b). Induction of microRNA-155 during Helicobacter pylori infection and its negative regulatory role in the inflammatory response. J. Infect. Dis. 200, 916-925.

Xiao, B., Zhu, E. D., Li, N., Lu, D. S., Li, W., Li, B. S., Zhao, Y. L., Mao, X. H., Guo, G., Yu, P. W., and Zou, Q. M. (2011). Increased miR-146a in gastric cancer directly targets SMAD4 and is involved in modulating cell proliferation and apoptosis. Oncol. Rep. doi: 10.3892/or.2011.1514. [Epub ahead of print].

Xu, X., Li, W., Fan, X., Liang, Y., Zhao, M., Zhang, J., Tong, W., Wang, J., Yang, W., and Lu, Y. (2007). Identification and characterization of a novel p42.3 gene as tumor-specific and mitosis phasedependent expression in gastric cancer. Oncogene 26, 7371-7379.

Yamanaka, Y., Tagawa, H., Takahashi, N., Watanabe, A., Guo, Y. M., Iwamoto, K., Yamashita, J., Saitoh, H., Kameoka, Y., Shimizu, N., Ichinohasama, R., and Sawada, K. (2009). Aberrant overexpression of microRNAs activate AKT signaling via down-regulation of tumor suppressors in natural killer-cell lymphoma/leukemia. Blood 114, 3265-3275.

Yang, Q., Jie, Z., Cao, H., Greenlee, A. R. Yang, C., Zou, F., and Jiang, Y. (2011). Low-level expression of let-7a in gastric cancer and its involvement in tumorigenesis by targeting RAB40C. Carcinogenesis 32, 713-722.

Yao, Y., Suo, A. L., Li, Z. F., Liu, L. Y., Tian, T., Ni, L., Zhang, W. G., Nan, K. J., Song, T. S., and Huang, C. (2009). microRNA profiling of human gastric cancer. Mol. Med. Report 2, 963-970.

Yoo, Y. D., Choi, J. Y., Lee, S. J., Kim, J. S., Min, B. R., Lee, Y. I., and Kang, Y. K. (1999). TGF-betainduced cell-cycle arrest through the p21(WAF1/CIP1)-G1 cyclin/Cdksp130 pathway in gastric-carcinoma cells. Int. J. Cancer 83, 512-517.

Zhang, Z., Li, Z., Gao, C., Chen, P., Chen, J., Liu, W., Xiao, S., and Lu, H. (2008). miR-21 plays a pivotal role in gastric cancer pathogenesis and progression. Lab. Invest. 88, 1358-1366.

Zhu, L. H., Liu, T., Tang, H., Tian, R. Q., Su, C., Liu, M., and Li, X. (2010a). microRNA-23a promotes the growth of gastric adenocarcinoma cell line MGC803 and downregulates interleukin-6 receptor. FEBS J. 277, 3726-3734.

Zhu, W., Shan, X., Wang, T., Shu, Y., and Liu, P. (2010b). miR-181b modulates multidrug resistance by targeting BCL2 in human cancer cell lines. Int. J. Cancer 127, 2520-2529.

Zhu, W., Xu, H., Zhu, D., Zhi, H., Wang, T., Wang, J., Jiang, B., Shu, Y., and Liu, P. (2011a). miR$200 \mathrm{bc} / 429$ cluster modulates multidrug resistance of human cancer cell lines by targeting BCL2 and XIAP. Cancer Chemother. Pharmacol. doi: 10.1007/s00280-011-17523. [Epub ahead of print].

Zhu, W., Zhu, D., Lu, S., Wang, T., Wang, J., Jiang, B., Shu, Y., and Liu, P. (2011b). miR-497 modulates multidrug resistance of human cancer cell lines by targeting BCL2. Med. Oncol. doi: 10.1007/s12032010-9797-4. [Epub ahead of print].

Conflict of Interest Statement: The authors declare that the research was conducted in the absence of any commercial or financial relationships that could be construed as a potential conflict of interest.

Received: 01 November 2011; accepted: 12 December 2011; published online: 03 January 2012.

Citation: Noto JM and Peek RM (2012) The role of microRNAs in Helicobacter pylori pathogenesis and gastric carcinogenesis. Front. Cell. Inf. Microbio. 1:21. doi: 10.3389/fcimb.2011.00021

Copyright (C) 2012 Noto and Peek. This is an open-access article distributed under the terms of the Creative Commons Attribution Non Commercial License, which permits non-commercial use, distribution, and reproduction in other forums, provided the original authors and source are credited. 


\section{APPENDIX}

Table A1 | miRNAs downregulated in gastric cancer.

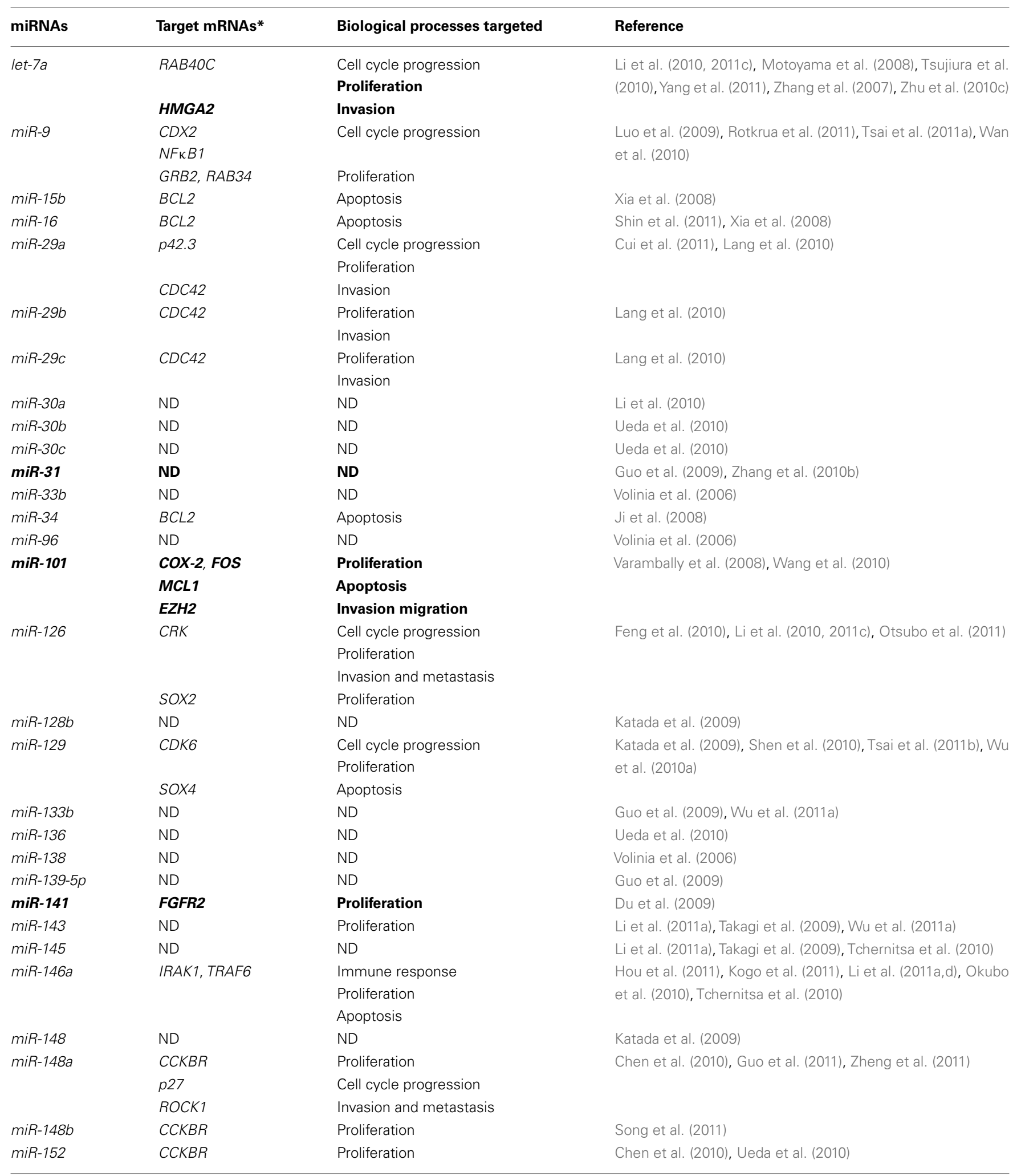


Table A1 | Continued

\begin{tabular}{|c|c|c|c|}
\hline miRNAs & Target mRNAs* & Biological processes targeted & Reference \\
\hline $\operatorname{miR}-181 b$ & $B C L 2$ & Apoptosis & Jiang et al. (2011), Li et al. (2011c), Zhu et al. (2010b) \\
\hline \multirow[t]{2}{*}{$\operatorname{miR}-181 c$} & NOTCH4, KRAS & Proliferation & Hashimoto et al. (2010), Zhu et al. (2010b) \\
\hline & $B C L 2$ & Apoptosis & \\
\hline $\operatorname{miR}-195$ & ND & ND & Guo et al. (2009), Wu et al. (2011a) \\
\hline $\operatorname{miR}-197$ & ND & ND & Li et al. (2011c) \\
\hline \multirow[t]{2}{*}{ miR-203 } & $A B L 1$ & Proliferation & Chiang et al. (2011), Craig et al. (2011b) \\
\hline & & Invasion & \\
\hline $\operatorname{miR}-210$ & ND & ND & Li et al. (2011c) \\
\hline $\operatorname{miR}-212$ & $\begin{array}{l}\text { MECP2 } \\
\text { MYC }\end{array}$ & Proliferation & $\begin{array}{l}\text { Volinia et al. (2006), Wada et al. (2010), Wu et al. (2011a), Xu } \\
\text { et al. (2010) }\end{array}$ \\
\hline \multirow[t]{3}{*}{$\operatorname{miR}-218$} & ECOP & Proliferation & Gao et al. (2010), Tie et al. (2010), Ueda et al. (2010), Volinia \\
\hline & & Apoptosis & et al. (2006) \\
\hline & ROBO1 & Invasion and metastasis & \\
\hline \multirow[t]{2}{*}{$\operatorname{miR}-331-3 p$} & E2F1 & Cell cycle progression & Guo et al. (2010) \\
\hline & & Proliferation & \\
\hline $\operatorname{miR}-339$ & ICAM-1 & Immune response & Ueda et al. (2009) \\
\hline \multirow[t]{2}{*}{$\operatorname{miR}-375$} & PDK1, 14-3-3 & Apoptosis & Ding et al. (2010), Tsukamoto et al. (2010), Ueda et al. (2010), \\
\hline & $J A K 2$ & Proliferation & Xu et al. (2011) \\
\hline $\operatorname{miR}-378$ & ND & ND & Guo et al. (2009), Yao et al. (2009) \\
\hline $\operatorname{miR}-433$ & GRB2 & Proliferation & Luo et al. (2009) \\
\hline \multirow[t]{2}{*}{$\operatorname{miR}-449$} & GMNN,CCNE2 & Cell cycle progression & Bou Kheir et al. (2011), Lize et al. (2011) \\
\hline & MET, SIRT1 & Proliferation & \\
\hline \multirow[t]{2}{*}{$\operatorname{miR}-451$} & MIF & Proliferation & Bandres et al. (2009) \\
\hline & & Apoptosis & \\
\hline $\operatorname{miR}-497$ & $B C L 2$ & Apoptosis & Guo et al. (2009), Zhu et al. (2011b) \\
\hline $\operatorname{miR}-512-5 p$ & MCL1 & Apoptosis & Saito et al. (2009) \\
\hline $\operatorname{miR}-638$ & ND & ND & Yao et al. (2009) \\
\hline $\operatorname{miR}-768-3 p$ & ND & ND & Guo et al. (2009) \\
\hline
\end{tabular}

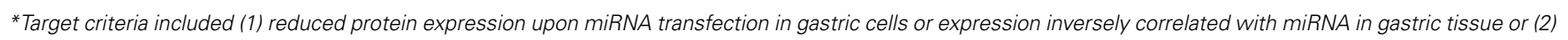

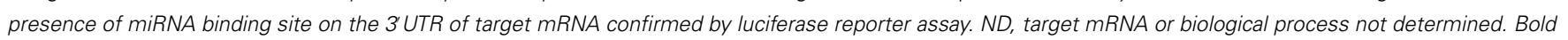
indicates miRNA also downregulated following $\mathrm{H}$. pylori infection. 
Table A2 | miRNAs upregulated in gastric cancer.

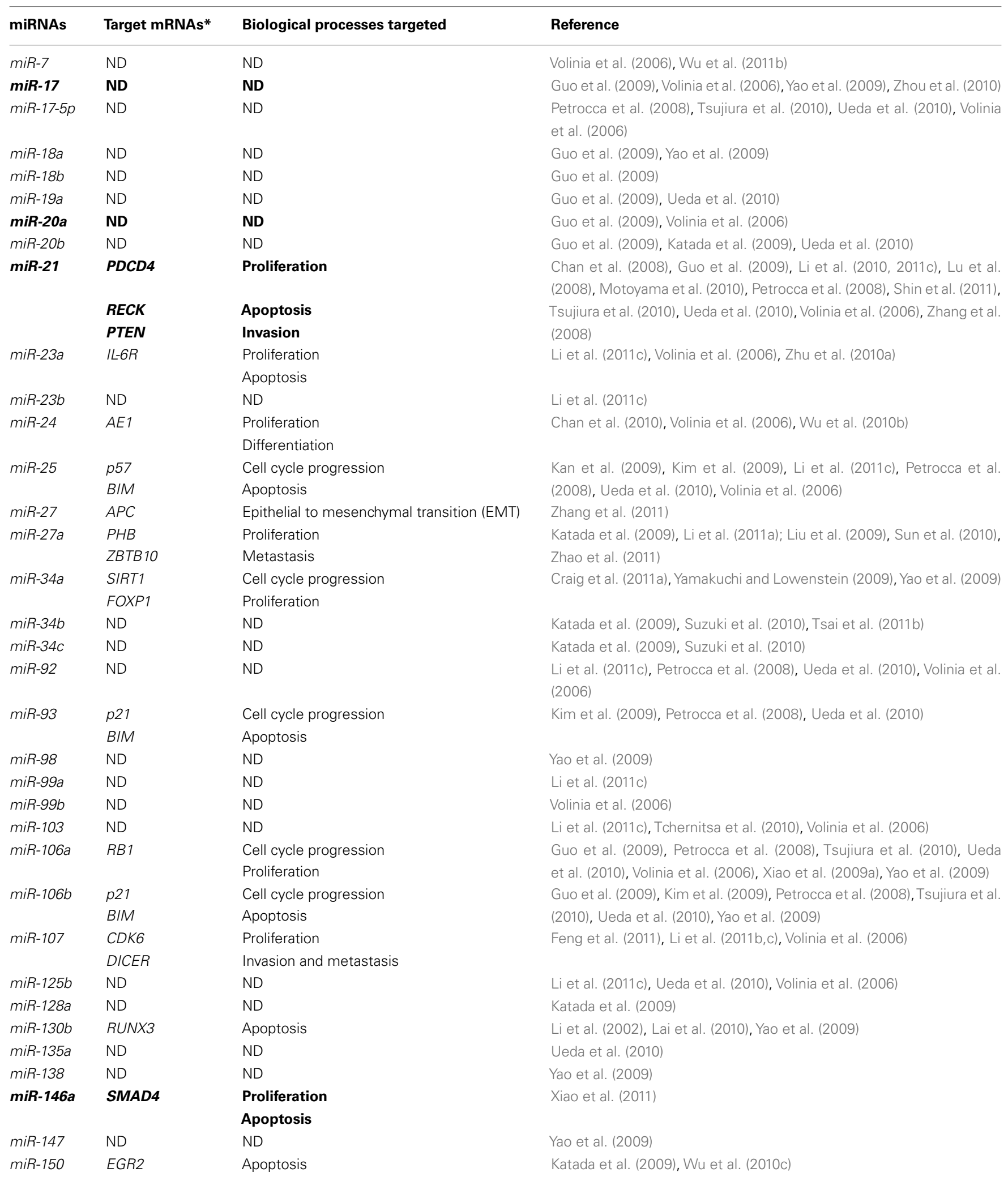


Table A2 | Continued

\begin{tabular}{|c|c|c|c|}
\hline miRNAs & Target mRNAs* & Biological processes targeted & Reference \\
\hline miR-155 & $\begin{array}{l}I K K-\varepsilon, S M A D 2 \\
F A D D, P K I_{\alpha}\end{array}$ & $\begin{array}{l}\text { Immune response } \\
\text { Apoptosis }\end{array}$ & $\begin{array}{l}\text { Fassi Fehri et al. (2010), Oertli et al. (2011), Tang et al. (2010), Thai } \\
\text { et al. (2007), Volinia et al. (2006), Xiao et al. (2009b), Yao et al. (2011) }\end{array}$ \\
\hline $\operatorname{miR}-185$ & ND & ND & Yao et al. (2009) \\
\hline $\operatorname{miR}-191$ & NDST1 & Proliferation & $\begin{array}{l}\text { Li et al. (2011c), Shi et al. (2011), Ueda et al. (2010), Volinia et al. } \\
\text { (2006) }\end{array}$ \\
\hline miR-196a & ND & ND & Okubo et al. (2010), Yao et al. (2009) \\
\hline miR-200a & ZEB1, ZEB2 & Epithelial to mesenchymal transition (EMT) & Ahn et al. (2011) \\
\hline $\operatorname{miR}-200 b$ & $\begin{array}{l}\text { ZEB1, ZEB2 } \\
B C L 2, X I A P\end{array}$ & $\begin{array}{l}\text { EMT } \\
\text { Apoptosis }\end{array}$ & Ahn et al. (2011), Zhu et al. (2011a) \\
\hline $\operatorname{miR}-214$ & ND & ND & Li et al. (2011c), Ueda et al. (2010), Volinia et al. (2006) \\
\hline miR-222 & $\begin{array}{l}\text { p27, p57 } \\
\text { PTEN } \\
\text { ICAM-1 }\end{array}$ & $\begin{array}{l}\text { Cell cycle progression } \\
\text { Proliferation } \\
\text { Immune response }\end{array}$ & $\begin{array}{l}\text { Chun-Zhi et al. (2010), Kim et al. (2009), Li et al. (2011c), Ueda et al. } \\
\text { (2009), Volinia et al. (2006) }\end{array}$ \\
\hline miR-223 & EPB41L3 & Invasion and metastasis & $\begin{array}{l}\text { Li et al. (2011c), Petrocca et al. (2008), Volinia et al. (2006), Yao et al. } \\
\text { (2009) }\end{array}$ \\
\hline $\operatorname{miR}-302 f$ & ND & ND & Yao et al. (2009) \\
\hline miR-337-3p & ND & ND & Yao et al. (2009) \\
\hline $\operatorname{miR}-340$ & ND & ND & Guo et al. (2009), Yao et al. (2009) \\
\hline $\operatorname{miR}-345$ & ND & ND & Ueda et al. (2010) \\
\hline $\operatorname{miR}-372$ & LATS2 & $\begin{array}{l}\text { Cell cycle progression } \\
\text { Apoptosis }\end{array}$ & Cho et al. (2009) \\
\hline $\operatorname{miR}-658$ & ND & ND & Guo et al. (2009) \\
\hline $\operatorname{miR}-1259$ & ND & ND & Yao et al. (2009) \\
\hline
\end{tabular}

*Target criteria included (1) reduced protein expression upon miRNA transfection in gastric cells or expression inversely correlated with miRNA in gastric tissue or (2) presence of miRNA binding site on the 3 UTR of target mRNA confirmed by luciferase reporter assay. ND, target mRNA or biological process not determined. Bold indicates miRNA also upregulated following $\mathrm{H}$. pylori infection. 


\section{REFERENCES}

Ahn, S. M., Cha, J. Y., Kim, J., Kim, D., Trang, H. T., Kim, Y. M., Cho, Y. H., Park, D., and Hong, S. (2011). Smad3 regulates E-cadherin via miRNA-200 pathway. Oncogene. doi: 10.1038/onc.2011.484. [Epub ahead of print].

Bandres, E., Bitarte, N., Arias, F., Agorreta, J., Fortes, P., Agirre, X., Zarate, R., Diaz-Gonzalez, J. A., Ramirez, N., Sola, J. J., Jimenez, P., Rodriguez, J., and GarciaFoncillas, J. (2009). microRNA451 regulates macrophage migration inhibitory factor production and proliferation of gastrointestinal cancer cells. Clin. Cancer Res. 15, 2281-2290.

Bou Kheir, T., Futoma-Kazmierczak, E., Jacobsen, A., Krogh, A., Bardram, L., Hother, C., Gronbaek, K., Federspiel, B., Lund, A. H., and Friis-Hansen, L. (2011). miR-449 inhibits cell proliferation and is down-regulated in gastric cancer. Mol. Cancer 10, 29-41.

Chan, M. C., Hilyard, A. C., Wu, C., Davis, B. N., Hill, N. S., Lal, A., Lieberman, J., Lagna, G., and Hata, A. (2010). Molecular basis for antagonism between PDGF and the TGFbeta family of signalling pathways by control of miR-24 expression. EMBO J. 29, 559-573.

Chan, S. H., Wu, C. W., Li, A. F., Chi, C. W., and Lin, W. C. (2008). miR21 microRNA expression in human gastric carcinomas and its clinical association. Anticancer Res. 28, 907-911.

Chen, Y., Song, Y., Wang, Z., Yue, Z., Xu, H., Xing, C., and Liu, Z. (2010). Altered expression of miR-148a and miR-152 in gastrointestinal cancers and its clinical significance. J. Gastrointest. Surg. 14, 1170-1179.

Chiang, Y., Song, Y., Wang, Z., Chen, Y., Yue, Z., Xu, H., Xing, C., and Liu, Z. (2011). Aberrant expression of miR-203 and its clinical significance in gastric and colorectal cancers. $J$. Gastrointest. Surg. 15, 63-70.

Cho, W. J., Shin, J. M., Kim, J. S., Lee, M. R., Hong, K. S., Lee, J. H., Koo, K. H., Park, J. W., and Kim, K. S. (2009). miR-372 regulates cell cycle and apoptosis of AGS human gastric cancer cell line through direct regulation of LATS2. Mol. Cells 28, 521-527.

Chun-Zhi, Z., Lei, H., An-Ling, Z., Yan-Chao, F., Xiao, Y., GuangXiu, W., Zhi-Fan, J., Pei-Yu, P., Qing-Yu, Z., and Chun-Sheng, K. (2010). microRNA-221 and microRNA-222 regulate gastric carcinoma cell proliferation and radioresistance by targeting PTEN. BMC Cancer 10, 367-377. doi:10.1186/1471-2407-10-367

Craig, V. J., Cogliatti, S. B., Imig, J., Renner, C., Neuenschwander, S., Rehrauer, H., Schlapbach, R., Dirnhofer, S., Tzankov, A., and Muller, A. (2011a). Myc-mediated repression of microRNA-34a promotes high-grade transformation of B-cell lymphoma by dysregulation of FoxP1. Blood 117, 6227-6236.

Craig, V. J., Cogliatti, S. B., Rehrauer, H., Wundisch, T., and Muller, A. (2011b). Epigenetic silencing of microRNA-203 dysregulates ABL1 expression and drives Helicobacterassociated gastric lymphomagenesis. Cancer Res. 71, 3616-3624.

Cui, Y., Su, W. Y., Xing, J., Wang, Y. C., Wang, P., Chen, X. Y., Shen, Z. Y., Cao, H., Lu, Y. Y., and Fang, J. Y. (2011). miR-29a inhibits cell proliferation and induces cell cycle arrest through the downregulation of $\mathrm{p} 42.3$ in human gastric cancer. PLoS ONE 6, e25872. doi:10.1371/journal.pone.0025872

Ding, L., Xu, Y., Zhang, W., Deng, Y., Si, M., Du, Y., Yao, H., Liu, X., Ke, Y., Si, J., and Zhou, T. (2010). miR-375 frequently downregulated in gastric cancer inhibits cell proliferation by targeting JAK2. Cell Res. 20, 784-793.

Du, Y., Xu, Y., Ding, L., Yao, H., Yu, H., Zhou, T., and Si, J. (2009). Down-regulation of miR-141 in gastric cancer and its involvement in cell growth. J. Gastroenterol. 44, 556-561.

Fassi Fehri, L., Koch, M., Belogolova, E., Khalil, H., Bolz, C., Kalali, B., Mollenkopf, H. J., Beigier-Bompadre, M., Karlas, A., Schneider, T., Churin, Y., Gerhard, M., and Meyer, T. F. (2010). Helicobacter pylori induces miR-155 in $\mathrm{T}$ cells in a cAMPFoxp3-dependent manner. PLoS ONE 5, e9500. doi:10.1371/journal.pone.0009500

Feng, L., Xie, Y., Zhang, H., and Wu, Y. (2011). miR-107 targets cyclin-dependent kinase 6 expression, induces cell cycle G1 arrest and inhibits invasion in gastric cancer cells. Med. Oncol. doi: 10.1007/s12032-011-9823-1. [Epub ahead of print].

Feng, R., Chen, X., Yu, Y., Su, L., Yu, B., Li, J., Cai, Q., Yan, M., Liu, B., and Zhu, Z. (2010). miR-126 functions as a tumour suppressor in human gastric cancer. Cancer Lett. 298, 50-63.

Gao, C., Zhang, Z., Liu, W., Xiao, S., Gu, W., and Lu, H. (2010). Reduced microRNA-218 expression is associated with high nuclear factor kappa $B$ activation in gastric cancer. Cancer 116, 41-49.

Guo, J., Miao, Y., Xiao, B., Huan, R., Jiang, Z., Meng, D., and Wang, Y. (2009). Differential expression of microRNA species in human gastric cancer versus non-tumorous tissues. J. Gastroenterol. Hepatol. 24, 652-657.

Guo, S. L., Peng, Z., Yang, X., Fan, K. J., Ye, H., Li, Z. H., Wang, Y., Xu, X. L., Li, J., Wang, Y. L., and Teng, Y. (2011). miR-148a promoted cell proliferation by targeting $\mathrm{p} 27$ in gastric cancer cells. Int. J. Biol. Sci. 7, 567-574.

Guo, X., Guo, L., Ji, J., Zhang, J., Chen, X., Cai, Q., Li, J., Gu, Q., Liu, B., Zhu, Z., and Yu, Y. (2010). miRNA-331$3 \mathrm{p}$ directly targets $\mathrm{E} 2 \mathrm{~F} 1$ and induces growth arrest in human gastric cancer. Biochem. Biophys. Res. Commun. 398, 1-6.

Hashimoto, Y., Akiyama, Y., Otsubo, T., Shimada, S., and Yuasa, Y. (2010). Involvement of epigenetically silenced microRNA-181c in gastric carcinogenesis. Carcinogenesis $31,777-784$.

Hou, Z., Xie, L., Yu, L., Qian, X., and Liu, B. (2011). microRNA-146a is downregulated in gastric cancer and regulates cell proliferation and apoptosis. Med. Oncol. doi: 10.1007/s12032011-9862-7. [Epub ahead of print].

Ji, Q., Hao, X., Meng, Y., Zhang, M., Desano, J., Fan, D., and Xu, L. (2008). Restoration of tumor suppressor miR-34 inhibits human p53-mutant gastric cancer tumorspheres. BMC Cancer 8, 266-278. doi:10.1186/1471-2407-8-266

Jiang, J., Zheng, X., Xu, X., Zhou, Q., Yan, H., Zhang, X., Lu, B., Wu, C., and Ju, J. (2011). Prognostic significance of miR-181b and miR-21 in gastric cancer patients treated with S-1/oxaliplatin or doxifluridine/oxaliplatin. PLoS ONE 6, e23271. doi:10.1371/journal.pone.0023271

Jiang, Z., Guo, J., Xiao, B., Miao, Y., Huang, R., Li, D., and Zhang, Y. (2010). Increased expression of miR421 in human gastric carcinoma and its clinical association. J. Gastroenterol. 45, 17-23.

Jin, Z., Selaru, F. M., Cheng, Y., Kan, T., Agarwal, R., Mori, Y., Olaru, A. V., Yang, J., David, S., Hamilton, J. P., Abraham, J. M., Harmon, J., Duncan, M., Montgomery, E. A., and Meltzer, S. J. (2011). microRNA-192 and -215 are upregulated in human gastric cancer in vivo and suppress ALCAM expression in vitro. Oncogene 30, 1577-1585.
Kan, T., Sato, F., Ito, T., Matsumura, N., David, S., Cheng, Y., Agarwal, R., Paun, B. C., Jin, Z., Olaru, A. V., Selaru, F. M., Hamilton, J. P., Yang, J., Abraham, J. M., Mori, Y., and Meltzer, S. J. (2009). The miR-106b25 polycistron, activated by genomic amplification, functions as an oncogene by suppressing p21 and Bim. Gastroenterology 136, 1689-1700.

Katada, T., Ishiguro, H., Kuwabara, Y., Kimura, M., Mitui, A., Mori, Y., Ogawa, R., Harata, K., and Fujii, Y. (2009). microRNA expression profile in undifferentiated gastric cancer. Int. J. Oncol. 34, 537-542.

Kim, Y. K., Yu, J., Han, T. S., Park, S. Y., Namkoong, B., Kim, D. H., Hur, K., Yoo, M. W., Lee, H. J., Yang, H. K., and Kim, V. N. (2009). Functional links between clustered microRNAs: suppression of cell-cycle inhibitors by microRNA clusters in gastric cancer. Nucleic Acids Res. 37, 1672-1681.

Kogo, R., Mimori, K., Tanaka, F., Komune, S., and Mori, M. (2011). Clinical significance of miR-146a in gastric cancer cases. Clin. Cancer Res. 17, 4277-4284.

Lai, K. W., Koh, K. X., Loh, M., Tada, K., Subramaniam, M. M., Lim, X., Vaithilingam, A., Salto-Tellez, M., Iacopetta, B., Ito, Y., and Soong, R. (2010). microRNA-130b regulates the tumour suppressor RUNX3 in gastric cancer. Eur. J. Cancer 46, 1456-1463.

Lang, N., Liu, M., Tang, Q. L., Chen, X., Liu, Z., and Bi, F. (2010). Effects of microRNA-29 family members on proliferation and invasion of gastric cancer cell lines. Chin. J. Cancer 29, 603-610.

Li, Q. L., Ito, K., Sakakura, C., Fukamachi, H., Inoue, K., Chi, X. Z., Lee, K. Y., Nomura, S., Lee, C. W., Han, S. B., Kim, H. M., Kim, W. J., Yamamoto, H., Yamashita, N., Yano, T., Ikeda, T., Itohara, S., Inazawa, J., Abe, T., Hagiwara, A., Yamagishi, H., Ooe, A., Kaneda, A., Sugimura, T., Ushijima, T., Bae, S. C., and Ito, Y. (2002). Causal relationship between the loss of RUNX3 expression and gastric cancer. Cell 109, 113-124.

Li, X., Luo, F., Li, Q., Xu, M., Feng, D., Zhang, G., and Wu, W. (2011a). Identification of new aberrantly expressed miRNAs in intestinaltype. Oncol. Rep. 26, 1431-1439.

Li, X., Zhang, Y., Shi, Y., Dong, G., Liang, J., Han, Y., Wang, X., Zhao, Q., Ding, J., Wu, K., and Fan, D. (2011b). microRNA-107, an oncogene microRNA that regulates tumour invasion and metastasis by targeting DICER1 in gastric cancer. J. Cell. Mol. Med. 15, 1887-1895. 
Li, X., Zhang, Y., Zhang, H., Liu, X., Gong, T., Li, M., Sun, L., Ji, G., Shi, Y., Han, Z., Han, S., Nie, Y., Chen, X., Zhao, Q., Ding, J., Wu, K., and Daiming, F. (2011c). miRNA-223 promotes gastric cancer invasion and metastasis by targeting tumor suppressor EPB41L3. Mol. Cancer Res. 9, 824-833.

Li, N., Xu, X., Xiao, B., Zhu, E. D., Li, B. S., Liu, Z., Tang, B., Zou, Q. M., Liang, H. P., and Mao, X. H. (2011d). H. pylori related proinflammatory cytokines contribute to the induction of miR-146a in human gastric epithelial cells. Mol. Biol. Rep. doi: 10.1007/s11033-011-1257-5. [Epub ahead of print].

Li, X., Zhang, Y., Ding, J., Wu, K., and Fan, D. (2010). Survival prediction of gastric cancer by a seven-microRNA signature. Gut 59, 579-585.

Liu, T., Tang, H., Lang, Y., Liu, M., and Li, X. (2009). microRNA-27a functions as an oncogene in gastric adenocarcinoma by targeting prohibitin. Cancer Lett. 273, 233-242.

Lize, M., Klimke, A., and Dobbelstein, M. (2011). microRNA-449 in cell fate determination. Cell Cycle 10, 2874-2882.

Lu, Z., Liu, M., Stribinskis, V., Klinge, C. M., Ramos, K. S., Colburn, N. H., and Li, Y. (2008). microRNA-21 promotes cell transformation by targeting the programmed cell death 4 gene. Oncogene 27, 4373-4379.

Luo, H., Zhang, H., Zhang, Z., Zhang, X., Ning, B., Guo, J., Nie, N., Liu, B., and Wu, X. (2009). Down-regulated miR-9 and miR-433 in human gastric carcinoma. J. Exp. Clin. Cancer Res. 28, 82-91.

Motoyama, K., Inoue, H., Mimori, K., Tanaka, F., Kojima, K., Uetake, H., Sugihara, K., and Mori, M. (2010). Clinicopathological and prognostic significance of PDCD4 and microRNA-21 in human gastric cancer. Int. J. Oncol. 36, 1089-1095.

Motoyama, K., Inoue, H., Nakamura, Y., Uetake, H., Sugihara, K., and Mori, M. (2008). Clinical significance of high mobility group A2 in human gastric cancer and its relationship to let-7 microRNA family. Clin. Cancer Res. 14, 2334-2340.

Oertli, M., Engler, D. B., Kohler, E., Koch, M., Meyer, T. F., and Muller, A. (2011). MicroRNA-155 is essential for the T cell-mediated control of Helicobacter pylori infection and for the induction of chronic gastritis and colitis. J. Immunol. 187, 3578-3586.

Okubo, M., Tahara, T., Shibata, T., Yamashita, H., Nakamura, M.,
Yoshioka, D., Yonemura, J., Ishizuka, T., Arisawa, T., and Hirata, I. (2010). Association between common genetic variants in pre-microRNAs and gastric cancer risk in Japanese population. Helicobacter 15, 524-531.

Otsubo, T., Akiyama, Y., Hashimoto, Y., Shimada, S., Goto, K., and Yuasa, Y. (2011). microRNA-126 inhibits SOX2 expression and contributes to gastric carcinogenesis. PLoS ONE 6, e16617. doi:10.1371/journal.pone.0016617

Petrocca, F., Visone, R., Onelli, M. R., Shah, M. H., Nicoloso, M. S., de Martino, I., Iliopoulos, D., Pilozzi, E., Liu, C. G., Negrini, M., Cavazzini, L., Volinia, S., Alder, H., Ruco, L. P., Baldassarre, G., Croce, C. M., and Vecchione, A. (2008). E2F1-regulated microRNAs impair TGFbeta-dependent cell-cycle arrest and apoptosis in gastric cancer. Cancer Cell 13, 272-286.

Rotkrua, P., Akiyama, Y., Hashimoto, Y., Otsubo, T., and Yuasa, Y. (2011). miR-9 downregulates CDX2 expression in gastric cancer cells. Int. J. Cancer 129, 2611-2620.

Saito, Y., Suzuki, H., Tsugawa, H., Nakagawa, I., Matsuzaki, J., Kanai, Y., and Hibi, T. (2009). Chromatin remodeling at Alu repeats by epigenetic treatment activates silenced microRNA512-5p with downregulation of Mcl1 in human gastric cancer cells. Oncogene 28, 2738-2744.

Shen, R., Pan, S., Qi, S., Lin, X., and Cheng, S. (2010). Epigenetic repression of microRNA-129-2 leads to overexpression of SOX4 in gastric cancer. Biochem. Biophys. Res. Commun. 394, 1047-1052.

Shi, X., Su, S., Long, J., Mei, B., and Chen, Y. (2011). microRNA-191 targets $\mathrm{N}$-deacetylase/N-sulfotransferase 1 and promotes cell growth in human gastric carcinoma cell line MGC803. Acta Biochim. Biophys. Sin. doi: 10.1093/abbs/gmr084. [Epub ahead of print].

Shin, V. Y., Jin, H., Ng, E. K., Cheng, A. S., Chong, W. W., Wong, C. Y., Leung, W. K., Sung, J. J., and Chu, K. M. (2011). NF-kappaB targets miR-16 and miR21 in gastric cancer: involvement of prostaglandin E receptors. Carcinogenesis 32, 240-245.

Song, Y. X., Yue, Z. Y., Wang, Z. N., Xu, Y. Y., Luo, Y., Xu, H. M., Zhang, X., Jiang, L., Xing, C. Z., and Zhang, Y. (2011). microRNA$148 \mathrm{~b}$ is frequently down-regulated in gastric cancer and acts as a tumor suppressor by inhibiting cell proliferation. Mol. Cancer 10, $1-13$.
Sun, Q., Gu, H., Zeng, Y., Xia, Y., Wang, Y., Jing, Y., Yang, L., and Wang, B. (2010). Hsa-mir-27a genetic variant contributes to gastric cancer susceptibility through affecting miR-27a and target gene expression. Cancer Sci. 101, 2241-2247.

Suzuki, H., Yamamoto, E., Nojima, M., Kai, M., Yamano, H. O., Yoshikawa, K., Kimura, T., Kudo, T., Harada, E., Sugai, T., Takamaru, H., Niinuma, T., Maruyama, R., Yamamoto, H., Tokino, T., Imai, K., Toyota, M., and Shinomura, Y. (2010). Methylation-associated silencing of microRNA-34b/c in gastric cancer and its involvement in an epigenetic field defect. Carcinogenesis 31, 2066-2073.

Takagi, T., Iio, A., Nakagawa, Y., Naoe, T., Tanigawa, N., and Akao, Y. (2009). Decreased expression of microRNA143 and -145 in human gastric cancers. Oncology 77, 12-21.

Tang, B., Xiao, B., Liu, Z., Li, N., Zhu, E. D., Li, B. S., Xie, Q. H., Zhuang, Y., Zou, Q. M., and Mao, X. H. (2010). Identification of MyD88 as a novel target of miR-155, involved in negative regulation of Helicobacter pylori-induced inflammation. FEBS Lett. 584, 1481-1486.

Tchernitsa, O., Kasajima, A., Schafer, R., Kuban, R. J., Ungethum, U., Gyorffy, B., Neumann, U., Simon, E., Weichert, W., Ebert, M. P., and Rocken, C. (2010). Systematic evaluation of the miRNA-ome and its downstream effects on mRNA expression identifies gastric cancer progression. J. Pathol. 222, 310-319.

Thai, T. H., Calado, D. P., Casola, S. Ansel, K. M., Xiao, C., Xue, Y., Murphy, A., Frendewey, D., Valenzuela, D., Kutok, J. L., Schmidt-Supprian, M., Rajewsky, N., Yancopoulos, G. Rao, A., and Rajewsky, K. (2007). Regulation of the germinal center response by microRNA-155. Science 316, 604-608.

Tie, J., Pan, Y., Zhao, L., Wu, K., Liu, J., Sun, S., Guo, X., Wang, B., Gang, Y., Zhang, Y., Li, Q., Qiao, T., Zhao, Q., Nie, Y., and Fan, D. (2010). miR-218 inhibits invasion and metastasis of gastric cancer by targeting the Robol receptor. PLoS Genet. 6, e1000879. doi:10.1371/journal.pgen.1000879

Tsai, K. W., Liao, Y. L., Wu, C. W., Hu, L. Y., Li, S. C., Chan, W. C., Ho, M. R., Lai, C. H., Kao, H. W., Fang, W. L., Huang, K. H., and Lin, W. C. (2011a). Aberrant hypermethylation of miR9 genes in gastric cancer. Epigenetics 6, 1189-1197.

Tsai, K. W., Wu, C. W., Hu, L. Y., Li, S. C., Liao, Y. L., Lai, C. H., Kao, H. W., Fang, W. L., Huang, K. H., Chan,
W. C., and Lin, W. C. (2011b). Epigenetic regulation of miR-34b and miR-129 expression in gastric cancer. Int. J. Cancer 129, 2600-2610.

Tsujiura, M., Ichikawa, D., Komatsu, S., Shiozaki, A., Takeshita, H., Kosuga, T., Konishi, H., Morimura, R., Deguchi, K., Fujiwara, H., Okamoto, K., and Otsuji, E. (2010). Circulating microRNAs in plasma of patients with gastric cancers. $\mathrm{Br}$. J. Cancer 102, 1174-1179.

Tsukamoto, Y., Nakada, C., Noguchi, T., Tanigawa, M., Nguyen, L. T., Uchida, T., Hijiya, N., Matsuura, K., Fujioka, T., Seto, M., and Moriyama, M. (2010). microRNA-375 is downregulated in gastric carcinomas and regulates cell survival by targeting PDK1 and 14-3-3zeta. Cancer Res. 70, 2339-2349.

Ueda, R., Kohanbash, G., Sasaki, K., Fujita, M., Zhu, X., Kastenhuber, E. R., McDonald, H. A., Potter, D. M., Hamilton, R. L., Lotze, M. T., Khan, S. A., Sobol, R. W., and Okada, H. (2009). Dicer-regulated microRNAs 222 and 339 promote resistance of cancer cells to cytotoxic Tlymphocytes by down-regulation of ICAM-1. Proc. Natl. Acad. Sci. U.S.A. 106, 10746-10751.

Ueda, T., Volinia, S., Okumura, H., Shimizu, M., Taccioli, C., Rossi, S., Alder, H., Liu, C. G., Oue, N., Yasui, W., Yoshida, K., Sasaki, H., Nomura S., Seto, Y., Kaminishi, M., Calin, G. A., and Croce, C. M. (2010). Relation between microRNA expression and progression and prognosis of gastric cancer: a microRNA expression analysis. Lancet Oncol. 11, 136-146.

Varambally, S., Cao, Q., Mani, R. S., Shankar, S., Wang, X., Ateeq, B., Laxman, B., Cao, X., Jing, X., Ramnarayanan, K., Brenner, J. C., Yu, J., Kim, J. H., Han, B., Tan, P., Kumar-Sinha, C., Lonigro, R. J., Palanisamy, N., Maher, C. A., and Chinnaiyan, A. M. (2008). Genomic loss of microRNA-101 leads to overexpression of histone methyltransferase EZH2 in cancer. Science 322 , 1695-1699.

Volinia, S., Calin, G. A., Liu, C. G., Ambs, S., Cimmino, A., Petrocca, F., Visone, R., Iorio, M., Roldo, C., Ferracin, M., Prueitt, R. L., Yanaihara, N., Lanza, G., Scarpa, A., Vecchione, A., Negrini, M., Harris, C. C., and Croce, C. M. (2006). A microRNA expression signature of human solid tumors defines cancer gene targets. Proc. Natl. Acad. Sci. U.S.A. 103, 2257-2261

Wada, R., Akiyama, Y., Hashimoto, Y., Fukamachi, H., and Yuasa, 
Y. (2010). miR-212 is downregulated and suppresses methyl-CpGbinding protein $\mathrm{MeCP} 2$ in human gastric cancer. Int. J. Cancer 127, 1106-1114.

Wan, H. Y., Guo, L. M., Liu, T., Liu, M., Li, X., and Tang, H. (2010). Regulation of the transcription factor NFkappaB1 by microRNA-9 in human gastric adenocarcinoma. Mol. Cancer 9, 16-26.

Wang, H. J., Ruan, H. J., He, X. J., Ma, Y. Y., Jiang, X. T., Xia, Y. J., Ye, Z. Y., and Tao, H. Q. (2010). microRNA101 is down-regulated in gastric cancer and involved in cell migration and invasion. Eur. J. Cancer 46, 2295-2303.

Wu, J., Qian, J., Li, C., Kwok, L., Cheng, F., Liu, P., Perdomo, C., Kotton, D., Vaziri, C., Anderlind, C., Spira, A., Cardoso, W. V., and Lu, J. (2010a). miR-129 regulates cell proliferation by downregulating Cdk6 expression. Cell Cycle 9, 1809-1818.

Wu, J., Zhang, Y. C., Suo, W. H., Liu, X. B., Shen, W. W., Tian, H., and Fu, G. H. (2010b). Induction of anion exchanger-1 translation and its opposite roles in the carcinogenesis of gastric cancer cells and differentiation of K562 cells. Oncogene 29, 1987-1996.

Wu, Q., Jin, H., Yang, Z., Luo, G., Lu, Y., Li, K., Ren, G., Su, T., Pan, Y., Feng, B., Xue, Z., Wang, X., and Fan, D. (2010c). miR-150 promotes gastric cancer proliferation by negatively regulating the pro-apoptotic gene EGR2. Biochem. Biophys. Res. Commun. 392, 340-345.

Wu, W. Y., Xue, X. Y., Chen, Z. J., Han, S. L., Huang, Y. P., Zhang, L. F., Zhu, G. B., and Shen, X. (2011a). Potentially predictive microRNAs of gastric cancer with metastasis to lymph node. World J. Gastroenterol. 17, 3645-3651.

Wu, X. M., Shao, X. Q., Meng, X. X., Zhang, X. N., Zhu, L., Liu, S. X., Lin, J., and Xiao, H. S. (2011b). Genome-wide analysis of microRNA and mRNA expression signatures in hydroxycamptothecin-resistant gastric cancer cells. Acta Pharmacol. Sin. 32, 259-269.

Xia, L., Zhang, D., Du, R., Pan, Y., Zhao, L., Sun, S., Hong, L., Liu, J., and Fan, D. (2008). miR-15b and miR16 modulate multidrug resistance by targeting BCL2 in human gastric cancer cells. Int. J. Cancer 123, 372-379.

Xiao, B., Guo, J., Miao, Y., Jiang, Z., Huan, R., Zhang, Y., Li, D., and Zhong, J. (2009a). Detection of miR-106a in gastric carcinoma and its clinical significance. Clin. Chim. Acta 400, 97-102.

Xiao, B., Liu, Z., Li, B. S., Tang, B., Li, W., Guo, G., Shi, Y., Wang, F., Wu, Y., Tong, W. D., Guo, H., Mao, X. H., and Zou, Q. M. (2009b). Induction of microRNA-155 during Helicobacter pylori infection and its negative regulatory role in the inflammatory response. J. Infect. Dis. 200, 916-925. Xiao, B., Zhu, E. D., Li, N., Lu, D. S., Li, W., Li, B. S., Zhao, Y. L., Mao, X. H., Guo, G., Yu, P. W., and Zou, Q. M. (2011). Increased miR-146a in gastric cancer directly targets SMAD4 and is involved in modulating cell proliferation and apoptosis. Oncol. Rep. doi: 10.3892/or.2011.1514. [Epub ahead of print].

Xu, L., Wang, F., Xu, X. F., Mo, W. H., Xia, Y. J., Wan, R., Wang, X. P., and Guo, C. Y. (2010). Downregulation of miR-212 expression by DNA hypermethylation in human gastric cancer cells. Med. Oncol. doi: 10.1007/s12032-010-9691-0. [Epub ahead of print].

Xu, Y., Deng, Y., Yan, X., and Zhou, T. (2011). Targeting miR-375 in gastric cancer. Expert Opin. Ther. Targets 15, 961-972.

Yamakuchi, M., and Lowenstein, C. J. (2009). miR-34, SIRT1 and p53: the feedback loop. Cell Cycle 8, 712-715.

Yang, Q., Jie, Z., Cao, H., Greenlee, A. R., Yang, C., Zou, F., and Jiang, Y. (2011). Low-level expression of let-7a in gastric cancer and its involvement in tumorigenesis by targeting RAB40C. Carcinogenesis 32, 713-722.

Yao, R., Ma, Y., Du, Y., Liao, M., Li, H., Liang, W., Yuan, J., Zhijunma, Yu, X., Xiao, H., and Liao, Y. (2011). The altered expression of inflammation-related microRNAs with microRNA-155 expression correlates with Th17 differentiation in patients with acute coronary syndrome. Cell. Mol. Immunol. doi 10.1038/cmi.2011.22. [Epub ahead of print].

Yao, Y., Suo, A. L., Li, Z. F., Liu, L. Y., Tian, T., Ni, L., Zhang, W. G., Nan, K. J., Song, T. S., and Huang, C. (2009). microRNA profiling of human gastric cancer. Mol. Med. Report 2, 963-970.

Zhang, H. H., Wang, X. J., Li, G. X., Yang, E., and Yang, N. M. (2007). Detection of let-7a microRNA by real-time PCR in gastric carcinoma. World J. Gastroenterol. 13 , 2883-2888.

Zhang, X., Zhu, W., Zhang, J., Huo, S., Zhou, L., Gu, Z., and Zhang, M. (2010a). microRNA-650 targets ING4 to promote gastric cancer tumorigenicity. Biochem. Biophys. Res. Commun. 395, 275-280.

Zhang, Y., Guo, J., Li, D., Xiao, B., Miao, Y., Jiang, Z., and Zhuo, H. (2010b). Down-regulation of miR-31 expression in gastric cancer tissues and its clinical significance. Med. Oncol. 27, 685-689.

Zhang, Z., Li, Z., Gao, C., Chen, P., Chen, J., Liu, W., Xiao, S., and Lu, H. (2008). miR-21 plays a pivotal role in gastric cancer pathogenesis and progression. Lab. Invest. 88, 1358-1366.

Zhang, Z., Liu, S., Shi, R., and Zhao, G. (2011). miR-27 promotes human gastric cancer cell metastasis by inducing epithelialto-mesenchymal transition. Cancer Genet. 204, 486-491.

Zhao, X., Yang, L., and $\mathrm{Hu}, \mathrm{J}$. (2011). Down-regulation of miR27a might inhibit proliferation and drug resistance of gastric cancer cells. J. Exp. Clin. Cancer Res. 30, 55-60.

Zheng, B., Liang, L., Wang, C., Huang, S., Cao, X., Zha, R., Liu, L., Jia, D., Tian, Q., Wu, J., Ye, Y. W., Wang, Q., Long, Z., Zhou, Y., Du, C., He, X., and Shi, Y. (2011). microRNA148a suppresses tumor cell invasion and metastasis by downregulating ROCK1 in gastric cancer. Clin. Cancer Res. doi: 10.1158/10780432.CCR-11-1714. [Epub ahead of print].

Zhou, H., Guo, J. M., Lou, Y. R., Zhang, X. J., Zhong, F. D., Jiang, Z., Cheng, J., and Xiao, B. X. (2010). Detection of circulating tumor cells in peripheral blood from patients with gastric cancer using microRNA as a marker. J. Mol. Med. 88, 709-717.

Zhu, L. H., Liu, T., Tang, H., Tian, R. Q., Su, C., Liu, M., and $\mathrm{Li}$, X. (2010a). microRNA-23a promotes the growth of gastric adenocarcinoma cell line MGC803 and downregulates interleukin- 6 receptor. FEBS J. 277, 3726-3734.

Zhu, W., Shan, X., Wang, T., Shu, Y., and Liu, P. (2010b). miR-181b modulates multidrug resistance by targeting BCL2 in human cancer cell lines. Int. J. Cancer 127, 2520-2529.

Zhu, Y. M., Zhong, Z. X., and Liu, Z. M. (2010c). Relationship between let-7a and gastric mucosa cancerization and its significance. World J. Gastroenterol. 16, 3325-3329.

Zhu, W., Xu, H., Zhu, D., Zhi, H., Wang, T., Wang, J., Jiang, B., Shu Y., and Liu, P. (2011a). miR$200 \mathrm{bc} / 429$ cluster modulates multidrug resistance of human cancer cell lines by targeting BCL2 and XIAP. Cancer Chemother. Pharmacol. doi: 10.1007/s00280-011-17523. [Epub ahead of print].

Zhu, W., Zhu, D., Lu, S., Wang, T., Wang, J., Jiang, B., Shu, Y., and Liu, P. (2011b). miR-497 modulates multidrug resistance of human cancer cell lines by targeting BCL2. Med. Oncol. doi: 10.1007/s12032010-9797-4. [Epub ahead of print]. 